\title{
AN ANALYSIS OF EUROPEAN BANKS SND ISSUES AND ITS IMPLICATIONS FOR THE DESIGN OF A MANDATORY SUBORDINATED DEBT POLICY
}

\author{
Andrea Sironi*
}

October 2000

\begin{abstract}
During the last twenty years an increasing number of proposals to improve bank market discipline through the introduction of a mandatory subordinated debt policy (MSDP) have been presented and critically discussed by academic economists and bank regulators. While theoretical issues are key in this debate, a proper understanding of the market of banks subordinated notes and debentures (SND) and of the securities main features is also considered as relevant for the potential introduction, design and goals setting of such a policy. This paper builds on information concerning issuers, investors, markets and securities technical features to critically discuss these aspects. Data on over 1,800 European banks SND issues completed during the 1988-2000:Q1 period together with information on primary and secondary market functioning is presented.
\end{abstract}

JEL Classification Numbers: G15, G21, G28

Keywords: bank, capital regulation, market discipline, subordinated debt

\footnotetext{
"Associate Professor of Financial Markets and Institutions, Bocconi University, Milan. This paper was prepared while the author was visiting the Federal Reserve Board. The views expressed in this paper are those of the author and do not necessarily reflect those of the Board of Governors, or members of its staff. The author wishes to thank Mark Flannery and an anonymous referee for their useful comments. All errors remain those of the author.
} 


\section{INTRODUCTION}

Since the early eighties a large number of proposals to improve bank market discipline with the introduction of a mandatory subordinated debt policy (MSDP) have been drafted by prominent academic economists, members of regulatory agencies and other independent organizations ${ }^{1}$. These proposals have recently received more attention by bank regulators as these, in turn, are increasingly willing to share the burden of monitoring and controlling banks' risk taking activities with capital market investors.

A MSDP is generally viewed by those in favor of such a policy as an ideal instrument to improve both direct and indirect market discipline because of four main reasons. First, subordinated debt reduces the incentives for banks to engage in excessive risk taking activities. This is because subordinated notes and debentures (SND) investors have similar incentives to those of the deposit insurance agencies: if banks increase their risk taking activities and these turn out profitable, SND investors, unlike equity holders, do not benefit from these gains. If, on the other side, an increase in bank risk taking activities is followed by losses that exceed banks' equity capital, SND holders, unlike insured creditors, bear much of the cost. Direct market discipline would therefore be improved as banks' cost of funds would be more directly related to their risk profile.

Second, as a risk-sensitive form of funding, subordinated debt represents an ideal candidate to improve indirect market discipline. Indeed, issuance and secondary market spreads with respect to a corresponding Treasury security would provide bank supervisors with valuable information on banks risk profiles and would therefore make it more difficult for them to forbear when intervention is necessary.

Third, a MSDP would provide stronger incentives for banks to disclose more information on their portfolio risks in a timely manner to the public. This would in turn reinforce both direct and indirect market discipline.

Finally, because of their typical long maturity, SND represent a stable source of funds and limit the risk of bank "runs", thereby mitigating the possibility of systemic risks. This

\footnotetext{
${ }^{1}$ See Board of Governors of the Federal Reserve System (1999) for a careful review. More recently, both the European and the U.S. Shadow Financial Regulatory Committees have issued similar proposals. See European Shadow Financial Regulatory Committee (2000) and U.S. Shadow Financial Regulatory Committee (2000).
} 
represents an advantage of SND with respect to other forms of uninsured bank liabilities, such as interbank deposits.

Despite the large number of MSDP proposals presented during the last twenty years, no serious effort to analyze the market of banks SND issues has been done so far, a relevant exception being represented by the recent study of the Federal Reserve Board (Board of Governors of the Federal Reserve System, 1999). A proper understanding of the primary and secondary market of banks' SND, together with an analysis of these securities technical features, is indeed relevant for the potential introduction, design and goal setting of such a policy.

This study is in the spirit of the one realized by the Federal Reserve Study Group in that it tries to fill this gap by analyzing data concerning issuers, investors, markets and securities structures and critically discussing the implications of this empirical evidence for the design of a MSDP. More precisely, data on over 1,800 European banks SND issues completed during the 1988-2000:Q1 period together with information on primary and secondary market functioning collected through interviews with market participants are presented.

No attempt is made by this study to contribute to the debate concerning the ability of a MSDP to improve market discipline by empirically investigating the risk-sensitivity of SND spreads ${ }^{2}$ or the ability of SND investors to influence banks management risk taking decisions $^{3}$. Rather, the opportunity of a MSDP represents an underlying assumption of this study, the attention of which is entirely focused on the design of such a policy. The empirical evidence presented in this paper shows three interesting results. First, the market for European banks' SND issues is a relatively concentrated one, with most of the supply coming from the largest banks. These institutions have significantly increased their SND issues since the introduction of the Capital Accord. They issue SND with an average frequency of twice a year and present an average ratio of outstanding subordinated debt to total assets slightly lower than $2 \%$. Second, despite the wide variety of security structures, the large majority of European banks' SND issues are plain vanilla, ten year maturity, fixed interest rate, non-callable coupon bonds. Finally, while often

\footnotetext{
${ }^{2}$ See Flannery (1998) for a review of the U.S. empirical studies of this type and Sironi (2000) for the European banking industry.
} 
listed in one or more European stock-exchanges for institutional investors needs, European banks SND are traded in a relatively illiquid secondary market, with few and infrequent large size transactions.

While the first two results are very similar to the ones observed for U.S. banks by the 1999 Federal Reserve Board Study Group on SND, some relevant differences between European and U.S. banks seem to exist as far as SND primary and secondary market functioning are concerned.

This empirical evidence has important policy implications for the evaluation of four main issues: (1) whether a MSDP should be mainly aimed at improving direct or indirect market discipline, (2) which banks should be subject to a MSDP, (3) the extent to which an internationally coordinated effort to harmonize the characteristics of an eventual MSDP is feasible, and (4) the "technical" design of a MSDP, with special reference to aspects such as minimum subordinated debt requirements, minimum frequency of issuance and security structures.

This paper proceeds as follows. Section 2 analyzes the main features of European banks SNDs issues since the introduction of the BIS Capital Accord in 1988 and provides information on the primary and secondary markets for such issues. Section 3 discusses the implications of this empirical evidence in terms of the design of a MSDP. Section 4 concludes.

\section{EUROPEAN BANKS SND ISSUES: EMPIRICAL EVIDENCE}

\subsection{Data sources}

Three main data sources have been used to collect information on European banks SND issues and subordinated debt outstanding: (1) Capital Data BondWare, (2) FitchIBCA BankScope, and (3) Moody's Corporate Default. Capital Data reports information on the major debt and equity issues worldwide. As far as bonds are concerned, Capital Data Bondware provides information on both issuers (nationality, Moody's and S\&P current ratings, industry, etc.) and issues (currency, announcement and closing dates, maturity date, years to maturity, issue type, face value, coupon, etc.). The Capital Data Bondware database contains information on 1,803 major SND issues by 225 European banks during

\footnotetext{
${ }^{3}$ See Bliss and Flannery (2000) and Covitz, Hancock and Kwast for this type of empirical studies.
} 
the period from January 1988 to March 2000, amounting to a total of US\$252,520 million equivalent amount (face value).

FitchIBCA BankScope is a database with information on financial statements, shareholders and subsidiaries of over 10,000 banks worldwide. It has been used to collect information on European, U.S. and Japanese banks subordinated debt outstanding and other key balance sheet figures from 1992 to 1999.

European banks issue SND either directly or through wholly owned subsidiaries located in fiscal havens such as Luxembourg, the Cayman Islands, the Netherland Antilles, the Channel Islands and the Bahamas ${ }^{4}$. Information on the ultimate parent company for these issues has been collected from both FitchIBCA Bankscope and Moody's Corporate Default database. The latter is a complete history of Moody's long-term rating assignments for both U.S. and non-U.S. corporations and sovereign. It also contains information on obligors such as borrower names, locations, CUSIP identifiers, ultimate parent companies, bond issuance dates, original maturity dates, seniority, and coupon.

\subsection{Issuers}

European banks significantly increased the amount of their subordinated debt funding since the Basel Capital Accord became fully effective in 1992. Table 2 reports data on the dollar value of subordinated debt outstanding from 1993 to 1999 for major E.U., U.S., Japanese and Swiss banks. With almost U.S.\$ 240 billion of subordinated debt outstanding as at 1999 year end, European banks represent the largest issuers of SND, accounting for over $46 \%$ of the total amount of bank subordinated debt worldwide ${ }^{5}$. This is mostly the consequence of recent issues, with the amount of SND outstanding for European banks almost tripling during the six years from 1993 to 1999. Indeed, Japanese banks had a larger amount of subordinated debt outstanding than E.U. banks at the end of 1993.

This significant increase of SND issues by European banks is strictly related to the Basel Capital Accord rules that allow subordinated debt to qualify as a bank's tier 2 and, more recently, tier 3 capital. Indeed, regulatory issues are considered by European banks as the most relevant factor behind the decision to issue SND as this type of funding is generally

\footnotetext{
${ }^{4}$ These issues account for almost $23 \%$ of total issues. See Table 10 for more data.
} 
perceived as a more expensive alternative to senior debt and would not be issued without this kind of motivation. Some European interviewed banks report that they tend to issue SND only if their capital adequacy situation is such that an increase in subordinated debt would improve their BIS capital ratio ${ }^{67}$.

Table 3 presents data on country averages of the ratio of subordinated debt to total assets (SD/TA) for banks with total assets in excess of U.S.\$ 50 billion. European Union banks present a lower ratio than Swiss, U.S. and Japanese banks at the end of 1999 (1.65\% versus $2.00 \%, 2.42 \%$ and $3.14 \%$ respectively). This evidence, coupled with a continuous increase in the SD/TA ratio during the last three years, suggests that a further increase in SND issues by European banks is likely for the near future. The SD/TA is lowest for German and French banks (1.06\% and 1.16\% respectively) and highest for Irish and UK banks $(3.10 \%$ and $2.22 \%$ respectively). However, all E.U. countries experienced an increase in their banks' SD/TA ratio during the last three years. While a clear explanation of this phenomenon is difficult to identify, three main reasons can be provided. First, the privatization of a large number of public banks in major European countries such as Italy and Spain led to a growing focus to shareholders value and, as a consequence, to an increasing attention on regulatory capital structure (tier 1 versus tier 2 capital). Indeed, the lowest 1999 average SD/TA ratios are the ones of French and German banks, a large number of which are still public. Second, European banks historically presented lower off-balance sheet activities than their U.S. counterparts. This is especially true for continental European banks and is in turn the consequence of the "banking oriented" - as opposed to "capital markets oriented" - nature of the European financial system. A lower development of investment banking activities such as securities underwriting and derivatives trading traditionally limited the growth of off-balance sheet assets for European banks. This in turn led to a lower ratio of risk-weighted assets (RWA) to total assets (TA). As shown by figure 3, in the mid-nineties this ratio was lower for continental European banks than for British, Irish, Japanese and U.S. ones. In a context where the SND issues are mostly driven by a regulatory rationale, this also led to a lower ratio of

\footnotetext{
${ }^{5}$ Note that the 240 billion of SND outstanding is consistent with the total U.S.\$252 billion of SND issues completed during the 1988-2000:Q1 period considering the average ten year maturity of these issues.

${ }^{6}$ This is the case if the total outstanding subordinated debt is lower than $50 \%$ of tier 1 capital. See Table 1.
} 
SD/TA. Following this argument, the recent increase in the RWA/TA for French, German, Italian and Spanish banks represents one of the reasons behind the growth in the SD/TA ratio. Indeed, this ratio remains lowest for French and German banks, which also experience a lower RWA/TA ratio.

As European banks get more and more involved in investments banking activities, the ratio $\mathrm{RWA} / \mathrm{TA}$ tends to increase and

The large number of major French and German is is also reflected in the lower than average SND issue size of French and German banks compared to other European banks (Table 7).

Table 4 reports data on the top 50 European bank issuers of $\mathrm{SND}^{8}$. All major 50 issuers rank within the 73 largest European banks (banks with 1999 year end total assets of over U.S.\$ 50 billion) with the only exception of the French bank Credit National (Table 4 and Appendix 1). These top 50 issuers account for $73 \%$ of the total 1,803 SND issues completed during the 1988-2000:Q1 period and for $83.9 \%$ of the total U.S.\$252,520 million of issued amount.

A significant portion (26\%) of the top 50 issuers of SND are public banks, i.e. banks which are either government owned or benefit from an explicit government guarantee. These banks have a clear advantage in issuing SND because the government guarantee generally gives them a top notch credit rating, allowing them to raise funds at cheaper rates than private-sector competitors ${ }^{9}$.

The average ratio between subordinated debt and risk-weighted assets (RWA) for the top 50 issuers is $5.19 \%$. This apparently contradicts the above-mentioned regulatory rationale behind the SND issuance decision. Indeed, a maximum 50\% of total Tier 1 capital is allowed to be computed as BIS capital, the latter being generally lower than $10 \%$ of RWA. However, total subordinated debt outstanding also includes SND issues with a

\footnotetext{
${ }^{7}$ Fiscal considerations are not considered a significant underlying factor of the decision to issue SND as these are again compared to senior debt and both type of funding interest rate expenses are tax-deductable.

${ }^{8}$ The ranking is based on the dollar amount of SND issued during the 1988-2000:Q1. An alternative criterium based on the number of issues would have produced similar results.

${ }^{9}$ See Sironi (2000) for a quantification of this interest rate subsidy.
} 
residual maturity of less than five years, which would only count as tier 2 capital for a limited portion of their total face value ${ }^{10}$.

The average frequency of issue for the top 50 issuers is twice a year, ranging from a maximum of four times for the largest banks to a minimum of 0.5 (one issue every two years) for the smallest ones.

\subsection{Investors}

Demand for European banks' SND comes both from retail and institutional investors. European banks raise subordinated debt in two main ways: (1) through their own distribution networks with private placements mainly targeted at private retail clients, and (2) through public issues targeted to institutional investors such as insurance companies, mutual and pension funds. The latter are generally larger size eurobond issues, underwritten and managed by large syndicates of international investment banks and listed in stock exchanges such as London and Luxembourg. Institutional investors also play a key role in secondary market transactions (see paragraph 2.6).

\subsection{Securities}

Tables 5, 6, 7 and 8 provide detailed information on the 1,803 SND issues. The characteristics of the average European bank subordinated debt issue are similar to the one issued by US bank holding companies (Board of Governors of the Federal Reserve System, 1999): a fixed rate, non-callable coupon bond with an average maturity of ten years and an average size of US\$ 240 million $^{11}$. Indeed, the large majority of the 19882000 issues are fixed-rate (74\%), with only a small portion of them being zero-coupon $(1.6 \%)$, convertible into floating rate $(0.8 \%)$ or including warrants for equity or senior debt $(0.5 \%)$. The remaining $26 \%$ of the issues are mostly represented by floating rate notes $(24.8 \%)$ and convertibles $(0.8 \%)$.

The average maturity of European banks' SND issues is 10.1 years, with 10 years representing the mode value not only for the whole sample but also for all but one country (Norway) and all years since 1992, when the Basel Capital Accord became

\footnotetext{
${ }^{10}$ In addition to this, data on RWA were not available for many smaller banks. As larger banks often present above average SD/RWA ratios, this lack of data has the effect of overestimating the sample banks $\mathrm{SD} / \mathrm{RWA}$ average ratio.

${ }^{11}$ This is the average face value for 1999 and 2000:Q1. The Federal Reserve Study Group on SND found the typical issue size for U.S. banks to be in the range of U.S.\$250 million to U.S.\$400 million.
} 
effective. While SND with a maturity ranging from 2 to 100 years have been issued by European banks, the typical maturity ranges from 5 to 15 years (Figure 1). This is mostly driven by the Basel Capital Accord rules, requiring subordinated debt to be amortized on a straight line basis over the five years preceding the maturity in order to qualify as tier 2 capital (Table 1). Indeed, figure 2 shows that the maturity distribution of European banks' SND issues changed since the Basel Capital Accord came into effect (end 1992), with a significant increase in the number of issues with a maturity equal and in excess of 10 years. More recently, following the 1997 introduction of tier 3 capital, which allowed SND issues with maturity above 2 years to qualify as regulatory capital for market risk requirements purposes, shorter maturity SND have been issued by major European banks. Over $50 \%$ of the SND issues with a maturity of less than 5 years have been completed in the 1997-2000:Q1 period $^{12}$.

Perpetual and callable issues represent $12.4 \%$ and $17.4 \%$ of the total SND issues respectively. A wide range of SND types are issued by European banks (collared, dual currency, reverse floaters, index-linked, etc.). However, these "irregular" securities only account for $15 \%$ of the total SND issues, the large majority ( $85 \%$ ) being represented by "plain vanilla" issues.

Table 5 reports information on single country banks SND issues. Four interesting points emerge. First, the average maturity is relatively higher for UK (13.35 years), Austrian (12.74 years), and Dutch (11.46) banks and relatively lower for Finnish (7.13 years) Norwegian (7.39 years), and Belgian (7.76 years) banks. Second, the average issue amount is relatively higher for UK $(\$ 315 \mathrm{~m})$, Spanish $(\$ 247 \mathrm{~m})$, Dutch $(\$ 235 \mathrm{~m})$, and Irish $(\$ 200 \mathrm{~m})$ banks. These are also the European countries where the banking industry is more concentrated. German and French banks, which contributed for the highest number of issues in the period, both reported lower than average issue amounts. Third, perpetual SND, amounting to $12.4 \%$ of the total number of issues, are mostly issued by Irish (54.5\%), UK (34\%) and Spanish (35\%) banks. This is partly a consequence of the previous aspect as perpetual issues have an average amount of US\$ 250 million, significantly above the global average. Finally, callable issues are relatively rare,

\footnotetext{
${ }^{12}$ Tier 3 capital was introduced by the BIS Amendment to the Capital Accord to Incorporate Market Risks in 1996, which became effective in 1997. See Basel Committee on Banking Supervision (1996).
} 
accounting for only $17.4 \%$ of the total number of subordinated issues. They are issued relatively more frequently by Irish (50\%), Portuguese (55\%), Norwegian (44\%), and UK $(40 \%)$ banks.

An analysis by year of issue (Table 6) highlights four main interesting features concerning the evolution of European banks SND issues. First, the number of European banks SND issues has been increasing, although not continuously, from just above 100 in 1988 to over 200 in 1999. Second, the average maturity has been increasing from approximately eight years in the late eighties to over ten years in the late nineties (12.1 years for 1999). However, since 1992, when the Basel Capital Accord came into effect, ten years maturity issues have always been the most common ones. Third, the average issue amount has been steadily increasing from a value of under U.S.\$100 million in the late eighties to over U.S.\$200 million in 1999 and 2000. This, coupled with the increase in the number of issues, led to a significant increase in the yearly dollar amount of European banks SND issues, from under $\$ 10$ billion in the late eighties to over U.S. $\$ 50$ billion in the late nineties. Finally, the numbers of perpetual and callable issues have both been increasing over time. While almost non-existent in the late eighties and early nineties, they represented over $20 \%$ and $30 \%$ respectively of the total number of issues in the late nineties. This is most likely a consequence of the prevailing interest rate environment: the expected rate decreases of the early eighties made perpetual and callable issues very unattractive to investors and, as a consequence, very costly to issuers. On the other side, the increasing rate scenario of the late nineties favored these kinds of issues.

Finally, a breakdown by currency of denomination (Table 7) shows three interesting points. First, Luxembourg franc is the most commonly used currency, accounting for over $25 \%$ of the total issues. These are mostly plain vanilla, fixed-rate, small size eurobonds, a significant portion (61\%) of which are then listed in the Luxembourg stock exchange for institutional investors needs. Second, most of the perpetual and callable SND issues are either U.S. dollar or pound sterling denominated issues, suggesting that U.S. and U.K. investors have an appetite for such issues while continental European investors prefer plain vanilla issues. Finally, Euro denominated issues, while accounting for only $15 \%$ of the total 1,803 SND issues completed by European banks in the 1988- 
2000:Q1 period, represent the majority of more recent issues (over 75\% of the 19992000:Q1 issues).

\subsection{The primary market}

Table 9 reports data on European banks SND issues by primary market type. Private placement issues, accounting for almost a third of the total number of SND issues, represent only $10.6 \%$ of their total U.S.\$252 billion face value. Their average size is significantly lower than the one of public issues. A large majority of the latter is represented by eurobond issues. These account for over $60 \%$ of the total number of SND issues and for over $64 \%$ of the total dollar value. The remaining $35 \%$ of the SND issues are divided between domestic ones (21\%), foreign ones (17\%) and global bonds (1\%). Global bonds represent very large size issues, with an average face value of over 600 million U.S. dollars, similar to eurobonds in that they are offered for sale in many countries simultaneously but different from them in that they are registered securities held in common depositories such as Cedel or Euroclear. This enhance secondary market trading in local markets and between investors in different regions.

\subsection{The secondary market}

According to interviewed market participants ${ }^{13}$, the secondary market for European banks SND issues is an over the counter dealer market dominated by large banks and institutional investors. Indeed, while most of the SND issues are listed in at least one exchange for institutional investors' needs ${ }^{14}$, few transactions take place in such exchanges.

It is a relatively illiquid over the counter market, with few and infrequent large size transactions. Indeed, most SND trade infrequently and in large blocks, with wide bid-ask spreads and relatively uninformative dealers quotes. Bid-ask spreads are reported to be in the range of 5 to 10 basis points during normal times ${ }^{15}$ for large size SND issued by

\footnotetext{
${ }^{13}$ Eight major banks from three major European countries (France, Italy and UK) were interviewed for this study. Six of them are both issuers of SND and market makers in the secondary market of European banks SND. Two of them are issuers only.

${ }^{14}$ Table 11 reports data on market listings. Almost $80 \%$ of European banks SND issues are listed in at least one exchange. Most issues are listed either in Luxembourg (38.9\%) or London (14.7\%).

15 This is higher than the 2 to 5 basis points value reported by the Federal Reserve Study Group for U.S. bank SND issues. See Board of Governors of the Federal Reserve System (1999), p. 49.
} 
major European banks ${ }^{16}$. However, spreads can significantly widen during market turbulence periods such as the one that followed the Russian default in August 1998 or other major events ${ }^{17}$. Liquidity is reported to be a function of two main factors: size and structure. Liquidity is higher for large size, plain-vanilla SND issued by major top rated European banks and almost non-existent for small size, irregular SND issues with options attached. Quoted prices by market makers do not generally represent a real commitment to buy or sell and are purely indicative ${ }^{18}$.

Investors in the secondary market of European banks' SND are mostly insurance companies, investment funds, pension funds and banks' asset management divisions. According to interviewed market participants, banks do not directly invest in other banks SND because of the capital adequacy rule requiring a bank to deduct the amount of these investments from its regulatory capital.

\section{IMPLICATIONS FOR THE DESIGN OF A MANDATORY SUBORDINATED DEBT POLICY}

Proposals to introduce a MSDP range from soft ones, aimed at complementing capital requirements, to more "radical" ones, aimed at replacing capital regulation. The latter generally focus on direct market discipline, the process whereby the expected cost of a bank funds is a direct function of its risk profile. On the other side, the "soft" proposals focus more on indirect market discipline. This can be defined as the process whereby the yields of a bank's risk-sensitive source of funds are used as a means for bank supervisors to improve their risk monitoring and controlling tasks. Proposals of this type range from more "discretionary" ones, where secondary market spreads of SND would be used by bank supervisors as market signals of the issuing banks' risk, to more "rigorous" ones, where changes in secondary market spreads would trigger regulatory actions such as prompt corrective actions (PCA).

\footnotetext{
${ }^{16}$ Two interviewed market participants report bid-offer spreads in price terms, of approximately 30 to 60 cents. This is equivalent to an interest rate based spread of 4 to 8 basis points for a ten year fixed rate SND issue with a $5 \%$ annual coupon.

${ }^{17}$ Liquidity crisis, default of comparable bonds and rating downgrades of similar issuers are generally mentioned by interviewed market participants as examples of these events.

${ }^{18}$ One interviewee indicated that an exception to this rule is represented by grey market quotes published by lead banks of syndicated issues for subordinated eurobonds.
} 
The 1999 Federal Reserve Study Group on SND carefully reviews the main proposals and classifies them into "three generations"19. First generation proposals were mostly made during the mid-eighties and were aimed at reinforcing direct market discipline by increasing a bank's cost of funding rather than by affecting its ability to obtain funds ${ }^{20}$. As such, they generally required banks to issue SND frequently, in order to keep their cost of capital in line with their evolving risk profile.

Second generation proposals were made during the late eighties and early nineties ${ }^{21}$. While still focused on the direct market discipline effect of subordinated debt, they emphasized the impact of a bank's risk profile on its ability to issue SND rather than on its cost of funding. Under these proposals, banks would be required to issue SND either on a frequent basis or with a provision allowing investors to put the debt back to the issuing bank. The inability of a bank to issue SND would then be used both as a signal of its financial weakness and as a trigger for regulatory action.

Third generation proposals are identified with the ones drafted by Calomiris in the late nineties (1997 and 1999). These proposals would require banks to issue on a very frequent basis (monthly rollover) short term SND (two years maturity) with a cap on the rate that they would be allowed to pay. Banks that do not manage to issue at rates under the rate cap would be required to gradually reduce their assets. As with previous proposals, the focus is on direct market discipline imposed in the issuance market.

More recent proposals presented by both the U.S. and European Shadow Financial Regulatory Committees ${ }^{22}$, while not providing details concerning technical aspects such as SND security structures and frequency of issuance, emphasized the role of subordinated debt as a means of reinforcing indirect market discipline and reducing bank supervisors' discretion in bank crisis management policies. Under this type of proposals, the distinction between tier 1 and tier 2 capital would be eliminated and banks would be subject to a simple leverage ratio that could be satisfied by both equity capital and subordinated debt.

\footnotetext{
${ }^{19}$ See Board of Governors of the Federal Reserve System (1999).

${ }^{20}$ See Benston et al (1986).

${ }^{21}$ These include Keehn (1988), Cooper and Fraser (1988), Wall (1989) and Evanoff (1993).

${ }^{22}$ See European Shadow Financial Regulatory Committee (2000) and U.S. Shadow Financial Regulatory Committee (2000).
} 


\subsection{Direct or indirect market discipline?}

In order to adequately design the technical features of a MSDP, a clear understanding of the main goal of such a policy is needed. This might appear as a trivial statement as no one would doubt that the basic goal of a MSDP is to improve bank market discipline. However, some key elements of a MSDP are affected by the choice between a direct market discipline oriented policy and an indirect market discipline oriented one. Direct market discipline to be effective requires a bank's expected cost of funds to be a direct function of its risk profile. This in turn requires that: (1) a significant portion of the bank's funding is in the form of uninsured risk-sensitive liabilities ${ }^{23}$, and (2) the bank access the debt market frequently enough for its borrowing costs to adequately reflect its evolving risk profile. Condition (1) requires that no conjectural guarantees such as "too big to fail" ones are perceived by subordinated investors to be in place. Indeed, this represent a necessary condition for a MSDP to be effective. While this issue is not explicitly treated by this paper, it is worth noting that currently available empirical research (Sironi, 2000) concluded that TPTF policies were present in the European banking industry in the first half of the nineties and became weaker or vanished during the second part of the decade. A much stronger and significant impact was found for explicit government guarantees such as the ones enjoyed by the German Landesbank. These explicit guarantees led to a significant government subsidy in the form of a lower cost of SND issues, the value of which has been increasing over the nineties.

In addition to that, no standardization of the SND securities would be needed for direct market discipline purposes. Both fixed rate and floating rate SND would serve the purpose of reinforcing direct market discipline, just as different maturity SND would.

On the other side, indirect market discipline requires the yield of SND to be both easily observable and comparable between different issuing banks. Secondary market spreads are therefore more relevant and their relationship to the evolving risk profiles of the issuing bank is crucial for its effectiveness. A portion of a bank's funds should be in the form of a risk-sensitive financial instrument traded in a liquid secondary market. In order to allow the supervisory authorities to make reasonable comparisons between the spreads

\footnotetext{
${ }^{23}$ If subordinated debt represents a minor portion of a bank's total liabilities, the majority of which is in the form of non risk-sensitive instruments, the bank management might not respond to market signals.
} 
of different banks SND, a high degree of standardization in the securities characteristics would be preferable, as this would also magnify secondary market liquidity. No significant amount or high frequency of issuance of SND is needed for the purpose of indirect market discipline ${ }^{24}$.

In light of the scarce liquidity of European banks SND secondary market, a MSDP mainly aimed at reinforcing direct market discipline would be advisable. However, the use of issuance spreads by bank supervisors as market signals of a bank financial soundness, without any automatic link to PCA type regulatory actions, could also be beneficial, introducing an indirect market discipline goal in the design of a MSDP ${ }^{25}$.

\subsection{Which banks?}

Most of the proposals to introduce a MSDP suggest that only large banks should be subject to such a policy. Indeed, SND are currently issued mostly, although not exclusively, by large banks with total assets in excess of U.S. \$ 50 billion. These banks account for over $83 \%$ of the total U.S.\$252 billion of SND issued by European banks during 1988-2000:Q1. This is not a sufficient condition for a MSDP to be limited to major banks. However, three additional arguments can be advanced. First, for a MSDP to be effective in improving direct market discipline, a minimum frequency of issue is required. If a bank issue subordinated debt only once every two year, its cost of funding would not adequately reflect the evolution of its risk profile. Table 4 shows that the frequency of issue is decreasing with the size of the issuing bank.

Second, for a MSDP to be effective in improving indirect market discipline, a minimum amount is required for each SND issue. Market participants report that the secondary market liquidity of an SND issue is a direct function of the issue amount and of the issuing bank size and "name".

\footnotetext{
${ }^{24}$ An exception would arise if the secondary market liquidity of an individual issue is partly driven by how long it has been outstanding. In such a case, a higher frequency of issue would enhance indirect market discipline. However, I am not aware of any study providing empirical evidence on this relationship.

${ }^{25}$ Interviewed market participants tend to be skeptical about the reliability of secondary market spreads as signals of the issuing banks' risk profiles for two main reasons. First, because, given the illiquidity of the market, spreads can be significantly affected by the decision to buy or sell of individual institutional investors. These could in turn be driven by reasons that are not directly related to the credit quality of the issuing bank, such as cash withdrawals for an investment fund. Second, because secondary market SND
} 
Finally, the need to improve both types of market discipline would be particularly strong for those banks that choose to adopt an internal model approach (IMA) to capital requirements. A future capital adequacy regime based on banks' internal risk measurement models poses a major problem for bank supervisors. Given the shareholders' option-like payoff profile, banks experiencing significant unexpected losses and getting closer to their default point could find it convenient to adopt a gaming behavior by artificially reducing the internally produced risk measures while increasing their risk taking activities in an effort to replenish their equity capital. The growing independence of bank management in determining their capital adequacy must therefore be accompanied by an increasing role of market forces in monitoring banks' risk profiles. Both the U.S. and the European experience following the Basel 1996 Amendment to the Capital Accord ${ }^{26}$ show that the largest banks are the most likely ones to choose this approach. Because of these reasons, a MSDP limited to those banks that choose an IMA, either in the form of an internal ratings based approach (IRA) to credit risk capital requirements or in the form of a IMA to market risk capital requirements, is considered appropriate. This solution could also represent a "transition period" during which no real obligation to satisfy a subordinated debt requirement would be in place, as banks would only face it in the event they choose for a IMA to capital standards.

\subsection{How much?}

Defining the amount of the appropriate required cushion of a MSDP requires to identify the relevant variable to which the subordinated debt requirement should be related. Most of the MSDP proposals drafted during the eighties, before the introduction of the 1988 Basel Capital Accord, were based either on bank liabilities or on bank deposits as the relevant variable ${ }^{27}$. On the other side, most of the proposals advanced during the nineties are based either on total risky (non-reserve) assets or risk-weighted assets (RWA) ${ }^{28}$. This evolution reflects both the belief that the required cushion should be directly related to a

\footnotetext{
spreads are considered to be driven more by short term market expectations than by the medium to long term "fundamentals" of the issuing banks.

${ }^{26}$ This amendment introduced the IMA alternative for market risk capital requirements purposes.

${ }^{27}$ Most of these proposals would require a minimum subordinated debt requirement ranging from $2 \%$ to $4 \%$ of total deposits or liabilities.

${ }^{28}$ Most of these proposals would require a minimum subordinated debt requirement ranging from $2 \%$ to $5 \%$ of risky or risk-weighted assets.
} 
bank's risk profile, and the idea that a MSDP should complement the existing capital adequacy framework and, as such, be based on the same relevant variable.

While the capital adequacy risk-weighting scheme suffers from the well known problems that open the door to regulatory arbitrage transactions, RWA have two clear advantages with respect to other balance sheet variables. First, they take into account off-balance sheet items and the related credit risk profile. Second, they introduce a basic differentiation between different assets credit risk profiles ${ }^{29}$. On the other side, relating the subordinated debt requirement to a bank's total RWA would create two main problems. First, it would confine the requirement to credit risk. This problem could be solved by including into the RWA variable the total exposure to market risk coming from the trading portfolio ${ }^{30}$. Second, it would open the door to regulatory arbitrage opportunities. This problem would be less relevant than it currently is because of the lower cost of subordinated debt capital compared to equity capital.

An alternative to a minimum ratio of RWA would be a MSDP based on a minimum portion of a bank total capital at risk, as measured by an IMA. This alternative has two main advantages. First, it would not confine the subordinated debt requirement to credit risk, by taking into consideration other types of risks, most notably market risks. Second, it would provide a subordinated debt requirement which is better related to a bank global portfolio risk than the one resulting from the sum of single assets risk-weighted requirements. On the other side, this alternative suffers from the moral hazard problem outlined above. MSDP is especially needed as a means to counterweight the trend towards a greater reliance on banks internal models based equity capital requirements because of the potential risk of "gaming" behavior on the part of these banks.

\footnotetext{
${ }^{29}$ The U.S. Shadow Financial Regulatory Committee (2000) claims that using a simple leverage ratio based on total assets would be equivalent, if not better, than a RWA related one because of its simplicity. This argument fails to consider that a simple leverage ratio is equivalent to attributing an identical $100 \%$ risk weight to all assets, thereby imposing the same capital charge to a AAA rated government bond and an unsecured loan to a CCC rated company. While a standardized and static differentiation of asset classes would never completely eliminate regulatory arbitrage opportunities, it is clear that these opportunities are lower the higher is the number of the risk buckets and the more refined is the risk-weighting scheme.

${ }^{30}$ This in turn could be obtained in two alternative ways: (1) by multiplying the standard approach market risk capital requirement by 12.5 (the reciprocal of $8 \%$ ), or (2) by adding the exposure of each single market risk factor such as the net open position in foreign currencies and the net open position in stocks for general equity risk.
} 
In light of the above arguments, a MSDP based on a bank RWA related requirement is considered, on balance, a better alternative. Table 4 reports the ratio of total outstanding subordinated debt to RWA for the 50 major European bank issuers of subordinated debt. This typically ranges from a minimum of $2 \%$ to a maximum of $8 \%$. This suggests that a minimum subordinated debt requirement of $3 \%$ to $4 \%$ of RWA, while forcing a minority of banks to increase their SND outstanding, would not significantly affect major European banks financial structure.

The Federal Reserve Board Study Group on SND suggests that a lower rate would be more appropriate ${ }^{31}$. This conclusion is based on two main arguments. First, given the current ratio of subordinated debt to RWA, an SND requirement in excess of 2 percent would have significant effects on the balance sheets of some banking organizations. Second, given many institutions preference for tier 1 over tier 2 capital, a high subordinated debt requirement could provide an incentive to substitute SND for equity capital, thereby weakening their overall capital structure.

A reply to these arguments could be based on the following three considerations. First, the total amount of a bank outstanding SND would qualify for subordinated debt requirement purposes, without any residual maturity restriction such as the five years one currently in place. This would make it easier for banks to comply. Second, once a MSDP is introduced for those banks opting for an IMA to capital requirement, the latter would most likely be based on equity, or tier 1, capital only. This in turn would reduce the risk of equity capital being substituted by subordinated debt. Finally, if the improvement of direct market discipline represents the main goal of a MSDP, then a significant amount of subordinated debt is needed for a bank's cost of funding to be affected.

\subsection{How frequently?}

Table 4 reports the average frequency of issue for the top 50 European bank issuers of SND. This ranges from a minimum of 0.5 (one issue every two years) for the smallest banks to a maximum of 4 to 5 times a year for the largest banks. However, these results are based on the 1988-2000 averages. As such, they include data from the late eighties and early nineties, when SND issues were less common and frequent for European banks (see Table 6). This evidence suggests that imposing a minimum frequency of issuance of 
twice a year, while forcing a minority of large banks to issue SND more frequently than they currently do, would not significantly affect major European banks' practices. This is especially true if the introduction of a MSDP is limited to those banks that opt for an IMA to capital requirements, typically the largest banks.

Requiring a higher frequency of issuance, such as three or four times a year, would probably be beneficial as a means of reinforcing both direct market discipline and "issuance spreads based" indirect market discipline. On the other side, it could significantly increase banks' borrowing costs by forcing them to issue SND during periods of adverse capital markets conditions.

One additional argument against a high frequency of issuance requirement is based on the increase in banks' borrowing costs that would result as a consequence of lower average SND issues $\operatorname{size}^{32}$. Empirical evidence based on European banks SND issues completed during the 1991-2000:Q1 period does not support this argument. Indeed, the size of SND issues is not statistically significant in explaining the variability of primary market SND spreads with respect to a corresponding Treasury security ${ }^{33}$. One could reply that the size of an SND issue could affect an SND issue secondary market spread. However, the issuing bank's borrowing cost is more directly related to the primary market spread.

\subsection{What type of SND?}

Finally, a MSDP could impose restrictions on the type of securities that qualify as subordinated debt. These restrictions could refer to elements such as maturity, interest rate type, call or put options, or special covenants. While reducing the flexibility of bank management decisions, such restrictions could reinforce both direct market discipline, by increasing SND investors incentives to monitor and control the issuing banks' risk taking activity, and indirect market discipline, by improving the comparability of SND spreads across banks and over time.

The cost-benefit analysis of such restrictions should therefore be based not only on their theoretical advantages from a market discipline point of view, but also on their impact on banks' prevailing practices. As far as the latter is concerned, the relatively high standardization of European banks' SND issues suggests that imposing such restrictions

${ }^{31}$ See Board of Governors of the Federal Reserve System (1999), p. 65.

${ }^{32}$ See Board of Governors of the Federal Reserve System (1999), p. 36. 
would not significantly affect banks' practices. More specifically, restricting the type of qualifying SND to non-convertible, non-callable securities with a minimum maturity of five years, while not significantly reducing major banks' flexibility, would likely improve bank supervisors possibility to compare SND issuance spreads and facilitate indirect market discipline ${ }^{34}$.

\subsection{How would the capital adequacy framework be affected by a MSDP?}

One final issue that must be evaluated when considering the introduction of a MSDP is the one related to the implications of such a policy for the current capital adequacy framework and, most notably, for the definition of capital. Subordinated debt currently qualifies, together with undisclosed reserves, revaluation reserves, general loan loss reserves and other hybrid debt capital instruments, as tier 2 capital. It also represents the only source of tier 3 capital (Table 1).

It is reasonable to assume that the introduction of a MSDP would eliminate the possibility for banks to rely on subordinated debt as a component of regulatory capital. This is considered, together with other changes in the definition of regulatory capital, especially appropriate for those banks that opt for an IMA to capital requirements. Indeed, much of the efforts to reform the capital adequacy framework are aimed at narrowing the gap between the way the banking industry and regulators measure the amount of capital a bank needs or, alternatively, its economic capital at risk. These efforts, in turn, are considered both as a means of improving the quantification of the amount of risk taken by banks, and as a way of reducing regulatory arbitrage incentives.

A bank economic capital at risk is generally defined by industry practitioners as the total unexpected loss a bank can suffer during a pre-defined time horizon - generally one year - with a pre-determined confidence level. A bank with a total economic capital at risk of U.S.\$ 1 billion computed using a one year time horizon and a 99.9\% confidence level should have a $0.1 \%$ probability of experiencing an unexpected loss in excess of that amount in the following year.

\footnotetext{
${ }^{33}$ See Sironi (2000).

${ }^{34}$ While most European banks' SND issues are fixed rate bonds, imposing a restriction on this element would seriously limit banks flexibility and, at the same time, not significantly increase spreads comparability.
} 
A key aspect of this definition of a bank's economic capital at risk is that it restricts the role of capital reserves to the unexpected component of the bank's total future losses, the expected component being covered by other types of reserves, such as loan loss reserves for credit risk. This distinction is crucial for the definition of the amount of capital a banking organization has available. Indeed, once an IMA is made available to the banking industry as an alternative to standardized capital requirements, then a similar logic as the one underlying internal risk measurement models should apply to the definition of capital. This would in turn require to restrict the regulatory definition of capital to tier 1.

\section{Conclusions}

This study has attempted to describe the main characteristics of European banks' SND issues, to examine the functioning of both the primary and secondary markets of these securities, and to critically discuss the implications of this empirical evidence for the design of a MSDP. No attempt has been made to provide empirical evidence to support the benefits of such a policy. Rather, the opportunity of a MSDP has been taken for granted by this study, the attention of which has been entirely focused on the design of such a policy.

Three main conclusions stand out from our analysis. First, the market for European banks' SND issues is a relatively concentrated one, with most of the supply coming from the largest banks. These institutions have significantly increased their SND issues since the introduction of the Capital Accord. They issue SND with an average frequency of twice a year and present an average ratio of outstanding subordinated debt to total assets slightly lower than $2 \%$. Second, despite the wide variety of security structures, the large majority of European banks' SND issues are plain vanilla, ten year maturity, fixed interest rate, non-callable coupon bonds. These characteristics are similar to the ones found by the 1999 Federal Reserve Study Group on SND for U.S. banks ${ }^{35}$. Third, while often listed in one or more European stock-exchanges for institutional investors needs, European banks SND are traded in a relatively illiquid secondary market, with few and infrequent large size transactions.

\footnotetext{
${ }^{35}$ Table 13 provides a comparison between European and U.S. banks' issues of SND.
} 
These conclusions have important implications for the design of a MSDP. First, the introduction of such a policy should be limited to the largest banks. The possibility of restricting the subordinated debt requirement to those banks that opt for an IMA to capital standards, rather than to banks with a minimum size, could represent an ideal way of achieving this objective. This would also allow a transition period without any real obligation for banks, during which bank supervisors could evaluate the impact and implications of such a policy.

Second, a MSDP should be mainly aimed at improving direct rather than indirect market discipline. As such, it should be based on a relatively high subordinated debt requirement, accompanied by a minimum frequency of issuance requirement.

Finally, given the many similarities between major European and U.S. banks' SND issuance practices and security structures, an internationally coordinated effort to harmonize the characteristics of a MSDP is considered both feasible and important. Indeed, most of the recent work to improve bank capital regulation has been carried out with an international focus through the Basel Committee. This is because of two main reasons. First, independent national regulations are considered increasingly incompatible with the global nature of the activities of major banks, to which most of the recent and currently undergoing efforts to reform the capital adequacy framework are addressed. Second, any independent attempt by single national authorities to modify the existing capital adequacy framework would inevitably affect the relative competitiveness of large international banks, thereby violating the "level the playing field" principle. Both these arguments apply to the eventual introduction of a MSDP. 


\section{REFERENCES}

Basel Committee on Banking Supervision, 1988, "International Convergence of Capital Measurement and Capital Standards", July.

Benston, G., R.A. Eisenbeis, P.M. Horvitz, E. Kane and G.C. Kaufman, 1986, Perspectives on Safe and Sound Banking, MIT Press: Cambridge, MA.

Bliss, Robert R. and Mark J. Flannery, 2000, Market Discipline in the Governance of U.S. Bank Holding Companies: Monitoring vs. Influencing, Working Paper Series 2000-03, Federal Reserve Bank of Chicago.

Board of Governors of the Federal Reserve System, 1999, "Using Subordinated Debt as an Instrument of Market Discipline", Study Group on Subordinated Notes and Debentures of the Federal Reserve System, Staff Study 172.

Calomiris, Charles W., 1997, The Postmodern Bank Safety Net: Lessons from Developed and Developing Countries, Washington, D.C., American Enterprise Institute.

Calomiris, Charles W., 1999, "Building an incentive-compatible safety-net", Journal of Banking \& Finance 23, 1499-1519.

Cooper, K., and D. R. Fraser, 1998, "The Rising Cost of Bank Failures: A Proposed Solution", Journal of Retail Banking, vol. 10, pp. 5-12.

Covitz, Daniel M., Diana Hancock and Myron Kwast, 2000, Mandatory Subordinated Debt: Would Banks Face More Market Discipline?, Board of Governors of the Federal Reserve System, unpublished paper.

European Shadow Financial Regulatory Committee, 2000, Internal Ratings Capital Standards and Subordinated Debt, Statement No. 7, Brussels, 7 February.

Evanoff, D.D., 1993, "Preferred Sources of Market Discipline", Yale Journal on Regulation, vol. 10, pp. 347-67.

Flannery, Mark J., 1998, "Using Market Information in prudential Bank Supervision: a Review of the U.S. Empirical Evidence", Journal of Money, Credit and Banking, 30, 273-305.

Keehn, S., 1988, Banking on the Balance: Powers and the Safety Net: A Proposal, Federal Reserve Bank of Chicago.

Sironi, Andrea, 2000, Testing for Market Discipline in the European Banking Industry: Evidence from Subordinated Debt Issues, paper presented at a Federal Reserve Board seminar, Washington, July 12.

U.S. Shadow Financial Regulatory Committee, 2000, Reforming Bank Capital Regulation, Statement No. 160, The AEI Press, American Enterprise Institute, March.

Wall, L.D., 1989, “A Plan for Reducing Future Deposit Insurance Losses: Putable Subordinated Debt”, Federal Reserve of Atlanta, Economic Review, vol. 74, pp. 2-17. 
Table 1 - Definition of Capital within the Basel Capital Accord

\begin{tabular}{|c|c|c|}
\hline Capital Component & Condition & Requirement \\
\hline TIER 1 & & $\begin{array}{l}\text { Minimum } 4 \text { percent of total } \\
\text { risk-weighted assets }\end{array}$ \\
\hline \multicolumn{3}{|l|}{ Paid-up share capital/common stock } \\
\hline \multicolumn{3}{|l|}{ Perpetual non-cumulative preference shares/stock } \\
\hline $\begin{array}{l}\text { Disclosed reserves (share premiums, retained profit, } \\
\text { legal reserves, fund for general banking risks, other } \\
\text { general funds/reserves) }\end{array}$ & $\begin{array}{l}\text { General funds/reserves must meet the following criteria: 1) allocations must be made out of post-tax retained } \\
\text { earnings or out of pre-tax earnings adjusted for all potential liabilities, 2) funds and movements into or out of } \\
\text { them must be disclosed separately in the banks accounts, 3) the funds must be available to a bank to meet losses } \\
\text { for unrestricted and immediate use as soon as they occur, 4) losses cannot be charged directly to the funds but } \\
\text { must be taken through the P\&L account }\end{array}$ & \\
\hline UPPER TIER 2 & & $\begin{array}{l}\text { Maximum } 100 \text { percent of } \\
\text { tier } 1 \text { capital }\end{array}$ \\
\hline Undisclosed Reserves & $\begin{array}{l}\text { 1) Passed through the profit and loss account. 2) Not encumbered by any provision or other known liability. 3) } \\
\text { Freely and immediately available to meet unforeseen future losses. 4) Accepted by the bank's supervisory } \\
\text { authorities. }\end{array}$ & \\
\hline Asset Revaluation Reserves & $\begin{array}{l}\text { Asset revaluation reserves that take the form of latent gains on unrealised securities are subject to a discount of } \\
55 \% \text { on the difference between historic book value and market value. }\end{array}$ & \\
\hline General provisions/general loan-loss reserves & $\begin{array}{l}\text { Only if held against presently unidentified losses. Where they include amounts reflecting lower valuations of } \\
\text { asset or latent but unidentified losses present in the balance-sheet, the amount of such provisions or reserves } \\
\text { will be limited to } 1.25 \text { percent points of weighted risk assets }\end{array}$ & \\
\hline $\begin{array}{l}\text { Hybrid debt capital instruments (cumulative } \\
\text { preference shares, perpetual subordinated debt) }\end{array}$ & $\begin{array}{l}\text { 1) Unsecured, subordinated and fully paid-up. 2) Not redeemable at the initiative of the holder or without the } \\
\text { prior consent of the supervisory authority. 3) Available to participate in losses without the bank being obliged } \\
\text { to cease trading. 4) Must allow service obligations to be deferred where the profitability of the bank would not } \\
\text { support payment. }\end{array}$ & \\
\hline \multicolumn{3}{|l|}{ LOWER TIER 2} \\
\hline Subordinated term debt & $\begin{array}{l}\text { Minimum original term to maturity of over five years. Subject to amortization ( } 20 \text { percent discount every year } \\
\text { if maturity less than five years). }\end{array}$ & $\begin{array}{l}\text { Maximum } 50 \text { percent of tier } \\
1 \text { capital }\end{array}$ \\
\hline \multicolumn{3}{|c|}{ ( } \\
\hline Subordinated term debt & $\begin{array}{l}\text { 1) Can only be used to cover market risk capital requirement from the trading book. 2) Minimum original } \\
\text { maturity of over two years. } 3 \text { ) Must contain interest payments and principal repayment deferral provisions, } \\
\text { which can be exercised if the minimum capital adequacy ratio is breached. }\end{array}$ & $\begin{array}{l}\text { Maximum } 250 \% \text { of tier } 1 \\
\text { capital for market risks }\end{array}$ \\
\hline \multicolumn{3}{|l|}{ DEDUCTIONS } \\
\hline Goodwill & & Deducted from tier 1 \\
\hline $\begin{array}{l}\text { Investments in unconsolidated banking and financial } \\
\text { subsidiaries }\end{array}$ & & Deducted from total capital \\
\hline Holdings of other banks' capital & Deduction is at the discretion of national supervisory authorities & Deducted from total capital \\
\hline
\end{tabular}

Source: Basel Committee on Banking Supervision (1988) and following amendments. 
Table 2. Total Subordinated Debt Outstanding (US\$bn)

Major Banks (Banks with Total Assets in excess of US\$ 50bn as at 12/99)

\begin{tabular}{|l|c|c|c|c|c|c|c|}
\hline & $\mathbf{1 9 9 3}$ & $\mathbf{1 9 9 4}$ & $\mathbf{1 9 9 5}$ & $\mathbf{1 9 9 6}$ & $\mathbf{1 9 9 7}$ & $\mathbf{1 9 9 8}$ & $\mathbf{1 9 9 9}$ \\
\hline EU & 85.746 & 106.642 & 129.101 & 148.182 & 173.295 & 202.492 & 239.948 \\
\hline JAPAN $\left(^{*}\right)$ & 94.453 & 104.407 & 134.396 & 132.853 & 131.704 & 139.054 & 166.742 \\
\hline USA & 31.984 & 36.467 & 44.912 & 59.311 & 66.013 & 87.178 & 88.493 \\
\hline SWI & 8.534 & 9.733 & 13.533 & 14.584 & 16.754 & 21.747 & 21.013 \\
\hline TOTAL & 220.716 & 257.248 & 321.942 & 354.929 & 387.766 & 450.470 & 516.195 \\
\hline
\end{tabular}

(*) Year end March 1999. Source: FitchIBCA.

Table 3. Average Ratio Subordinated Debt/Total Assets

Major Banks (Banks with Total Assets in excess of US\$ 50bn as at 12/99)

\begin{tabular}{|l|c|c|c|c|}
\hline Country & $\mathbf{1 9 9 9}$ & $\mathbf{1 9 9 8}$ & $\mathbf{1 9 9 7}$ & $\mathbf{1 9 9 6}$ \\
\hline AUSTRIA & $2.22 \%$ & $2.38 \%$ & $2.11 \%$ & $1.61 \%$ \\
\hline BELGIUM & $2.05 \%$ & $2.05 \%$ & $1.98 \%$ & $1.85 \%$ \\
\hline DENMARK & $1.88 \%$ & $1.61 \%$ & $1.39 \%$ & $0.49 \%$ \\
\hline FRANCE & $1.16 \%$ & $1.23 \%$ & $1.06 \%$ & $1.07 \%$ \\
\hline GERMANY & $1.06 \%$ & $0.94 \%$ & $1.00 \%$ & $0.81 \%$ \\
\hline IRELAND & $3.10 \%$ & $1.73 \%$ & $1.96 \%$ & $1.90 \%$ \\
\hline ITALY & $1.69 \%$ & $1.23 \%$ & $0.99 \%$ & $1.01 \%$ \\
\hline NETHERLANDS & $1.34 \%$ & $1.30 \%$ & $1.37 \%$ & $1.43 \%$ \\
\hline SPAIN & $1.90 \%$ & $1.51 \%$ & $1.32 \%$ & $1.33 \%$ \\
\hline SWEDEN & $1.56 \%$ & $1.69 \%$ & $1.75 \%$ & $1.87 \%$ \\
\hline UNITED KINGDOM & $2.22 \%$ & $1.43 \%$ & $1.43 \%$ & $1.52 \%$ \\
\hline Total EU & $\mathbf{1 . 6 5 \%}$ & $\mathbf{1 . 3 7 \%}$ & $\mathbf{1 . 3 3 \%}$ & $\mathbf{1 . 2 6 \%}$ \\
\hline SWITZERLAND & $2.00 \%$ & $1.98 \%$ & $1.56 \%$ & $1.45 \%$ \\
\hline USA & $2.42 \%$ & $2.47 \%$ & $2.36 \%$ & $2.54 \%$ \\
\hline JAPAN $(*)$ & $3.14 \%$ & $2.95 \%$ & $2.48 \%$ & $2.12 \%$ \\
\hline
\end{tabular}

(*) Year end March 1999. Source: FitchIBCA. 
Table 4 - European Banks: 50 Major Issuers of SNDs (1988-2000:Q1)

\begin{tabular}{|c|c|c|c|c|c|c|c|c|c|c|}
\hline & Issuer & \multicolumn{2}{|c|}{ N. of issues } & \multicolumn{2}{|c|}{ Amount (US\$ m) } & \multicolumn{5}{|c|}{ Issuing Bank (U.S.\$ m) } \\
\hline Rank & & Total & Avg.Year & Total & Avg. issue & Tot. Assets & Total RWA & Total SD & SD/TA & $\overline{\mathrm{SD} / \mathrm{RWA}}$ \\
\hline 1 & ABN AMRO Bank NV & 38 & 3.1 & 11,567 & 304 & 504,122 & 251,910 & 11,039 & $2.19 \%$ & $4.38 \%$ \\
\hline 2 & National Westminster Bank & 26 & 2.1 & 11,067 & 426 & 285,979 & 156,571 & 12,153 & $4.25 \%$ & $7.76 \%$ \\
\hline 3 & Lloyds TSB Group & 30 & 2.4 & 10,540 & 351 & 240,957 & 136,342 & 5,156 & $2.14 \%$ & $\overline{3.78 \%}$ \\
\hline 4 & Banco Santander C.H.A. & 39 & 3.2 & 10,145 & 260 & 255,549 & 163,796 & 8,117 & $3.18 \%$ & $4.96 \%$ \\
\hline 5 & Credit Suisse Group (*) & 62 & 5.1 & 9,517 & 153 & 475,018 & 146,815 & 12,031 & $2.53 \%$ & $8.19 \%$ \\
\hline 6 & Union Bank of Switzerland & 45 & 3.7 & 9,455 & 210 & 610,365 & 210,240 & 8,982 & $1.47 \%$ & $4.27 \%$ \\
\hline 7 & HSBC Holdings Plc & 29 & 2.4 & 9,202 & 317 & 599,777 & 302,598 & 12,188 & $2.03 \%$ & $4.03 \%$ \\
\hline 8 & Banca Intesa $\left(^{* *}\right)$ & 50 & 4.1 & 8,585 & 172 & 312,170 & 112,281 & 8,832 & $2.83 \%$ & $7.87 \%$ \\
\hline 9 & Abbey National plc & 22 & 1.8 & 8,082 & 367 & 263,183 & 122,880 & 5,294 & $2.01 \%$ & $4.31 \%$ \\
\hline 10 & Societe Generale & 52 & 4.2 & 7,514 & 145 & 407,478 & NA & 6,479 & $1.59 \%$ & NA \\
\hline 11 & Bayerische HypoVereinsbank & 49 & 4.0 & 7,134 & 146 & 483,981 & 252,996 & 9,401 & $1.94 \%$ & $3.72 \%$ \\
\hline 12 & Royal Bank of Scotland Group & 25 & 2.0 & 7,130 & 285 & 143,898 & 93,614 & 3,311 & $2.30 \%$ & $3.54 \%$ \\
\hline 13 & Dresdner Bank AG & 35 & 2.9 & 6,271 & 179 & 397,026 & 202,152 & 8,049 & $2.03 \%$ & $3.98 \%$ \\
\hline 14 & Barclays Bank plc & 22 & 1.8 & 6,141 & 279 & 397,660 & 186,860 & 4,590 & $1.15 \%$ & $2.46 \%$ \\
\hline 15 & Banco Bilbao Vizcaya Arg. $\left({ }^{* \star}\right)$ & 23 & 1.9 & 5,839 & 254 & 236,256 & 132,403 & 3,312 & $1.40 \%$ & $2.50 \%$ \\
\hline 16 & Commerzbank AG & 51 & 4.2 & 5,176 & 101 & 370,279 & 187,493 & 5,871 & $1.59 \%$ & $3.13 \%$ \\
\hline 17 & Halifax plc & 17 & 1.4 & 5,134 & 302 & 222,148 & 102,810 & 3,876 & $1.74 \%$ & $3.77 \%$ \\
\hline 18 & Deutsche Bank AG & 22 & 1.8 & 4,686 & 213 & 807,339 & 293,776 & 11,053 & $1.37 \%$ & $3.76 \%$ \\
\hline 19 & ING Groep & 21 & 1.7 & 4,611 & 220 & 495,092 & 181,540 & 7,974 & $1.61 \%$ & $4.39 \%$ \\
\hline 20 & BNP Paribas $\left(^{* \star}\right)$ & 41 & 3.3 & 4,299 & 105 & 701,787 & 214,670 & 10,005 & $1.43 \%$ & $4.66 \%$ \\
\hline 21 & MeritaNordbanken Group & 40 & 3.3 & 3,901 & 98 & 104,457 & 76,270 & 3,064 & $2.93 \%$ & $4.02 \%$ \\
\hline 22 & Almanij Kredietbank Group (*) & 46 & 3.8 & 3,827 & 83 & 198,213 & NA & 5,327 & $2.69 \%$ & NA \\
\hline 23 & Bank of Scotland & 15 & 1.2 & 3,772 & 251 & 143,898 & 74,560 & 3,248 & $2.26 \%$ & $4.36 \%$ \\
\hline 24 & Fortis Banque S.A. $\left({ }^{*}\right)$ & 49 & 4.0 & 3,359 & 69 & 323,538 & 156,152 & 7,142 & $1.43 \%$ & $2.96 \%$ \\
\hline 25 & Credit Agricole $\left(^{*}\right)$ & 49 & 4.0 & 3,236 & 66 & 440,506 & NA & 4,626 & $1.05 \%$ & NA \\
\hline 26 & Bayerische Landesbank GZ & 21 & 1.7 & 3,049 & 145 & 263,290 & NA & 3,965 & $1.51 \%$ & $\overline{N A}$ \\
\hline 27 & Westdeutsche Landesb.GZ $\left(^{*}\right)$ & 16 & 1.3 & 2,898 & 181 & 403,890 & NA & 4,371 & $1.08 \%$ & $\mathrm{NA}$ \\
\hline 28 & Groupe Banques Pop. $\left(^{\star}\right)$ & 36 & 2.9 & 2,858 & 79 & 92,189 & NA & 3,084 & $3.35 \%$ & NA \\
\hline 29 & San Paolo IMI $\left(^{*}\right)$ & 22 & 1.8 & 2,812 & 128 & 140,467 & 97,393 & 1,512 & $1.08 \%$ & $1.55 \%$ \\
\hline 30 & Skandinaviska Enskilda Bank & 23 & 1.9 & 2,278 & 99 & 86,301 & 38,726 & 914 & $1.06 \%$ & $2.36 \%$ \\
\hline 31 & Credit Lyonnais SA & 26 & 2.1 & 2,201 & 85 & 173,342 & 121,466 & 4,005 & $2.31 \%$ & $3.30 \%$ \\
\hline 32 & Den Danske Bank A/S & 10 & 0.8 & 2,104 & 210 & 98,958 & 58,027 & 3,021 & $3.05 \%$ & $5.21 \%$ \\
\hline 33 & Bankgesellschaft Berlin AG (*) & 14 & 1.1 & 2,048 & 146 & 217,785 & NA & 2,477 & $1.14 \%$ & NA \\
\hline 34 & Swedbank & 22 & 1.8 & 2,043 & 93 & 101,285 & 54,298 & 3,080 & $3.04 \%$ & $5.67 \%$ \\
\hline 35 & Dexia Group & 41 & 3.3 & 2,014 & 49 & 245,082 & 68,956 & 3,121 & $1.27 \%$ & $4.53 \%$ \\
\hline 36 & Bank of Ireland $\left(^{* * *}\right)$ & 6 & 0.5 & 1,888 & 315 & 54,507 & 33,466 & 874 & $1.60 \%$ & $2.61 \%$ \\
\hline 37 & Bank Austria & 21 & 1.7 & 1,812 & 86 & 140,267 & 82,461 & 3,632 & $2.59 \%$ & $4.40 \%$ \\
\hline 38 & Allied Irish Banks plc & 8 & 0.7 & 1,660 & 208 & 65,396 & 49,406 & 1,989 & $3.04 \%$ & $4.02 \%$ \\
\hline 39 & Woolwich Plc & 9 & 0.7 & 1,598 & 178 & 53,332 & 26,114 & 1,361 & $2.55 \%$ & $5.21 \%$ \\
\hline 40 & Landesbank Baden-Wurt. ( $\left.{ }^{\star}\right)$ & 6 & 0.5 & 1,427 & 238 & 250,317 & NA & 3,794 & $1.52 \%$ & NA \\
\hline 41 & Norddeutsche Landesb. GZ (*) & 21 & 1.7 & 1,275 & 61 & 169,109 & $\overline{N A}$ & 1,829 & $1.08 \%$ & $\overline{N A}$ \\
\hline 42 & Credit Mut. Centre Est Eur. $\left(^{*}\right)$ & 23 & 1.9 & 1,199 & 52 & 168,059 & NA & 2,636 & $1.57 \%$ & NA \\
\hline 43 & Banque Generale du Lux. $\left(^{*}\right)$ & 21 & 1.7 & 1,019 & 49 & 35,685 & NA & 630 & $1.77 \%$ & NA \\
\hline 44 & Credit National $\left({ }^{\star \star \star}\right)$ & 8 & 0.7 & 978 & 122 & 55,080 & $\overline{N A}$ & 1,435 & $2.60 \%$ & NA \\
\hline 45 & Unicredito Italiano & 6 & 0.5 & 874 & 146 & 169,708 & 104,332 & 1,412 & $0.83 \%$ & $1.35 \%$ \\
\hline 46 & Landesbank Hessen-Thur. GZ & 7 & 0.6 & 847 & 121 & 113,678 & NA & 897 & $0.79 \%$ & NA \\
\hline 47 & DG Bank Deutsche Genos. $\left(^{*}\right)$ & 11 & 0.9 & 782 & 71 & 256,926 & NA & 2,531 & $0.99 \%$ & NA \\
\hline 48 & IKB Deutsche Industriebank(*) & 10 & 0.8 & 743 & 74 & 29,667 & NA & 507 & $1.71 \%$ & $\overline{N A}$ \\
\hline 49 & Credit Commercial de France & 16 & 1.3 & 646 & 40 & 69,452 & NA & 697 & $1.00 \%$ & NA \\
\hline 50 & Landesb. Schleswig-Hol.GZ( $\left.{ }^{\star}\right)$ & 13 & 1.1 & 616 & 47 & 113,919 & 53,706 & 1,317 & $2.15 \%$ & $4.56 \%$ \\
\hline & Total & 1315 & 2.1 & 211,860 & 161 & $12,988,369$ & $4,547,081$ & 236,213 & $1.82 \%$ & $5.19 \%$ \\
\hline
\end{tabular}

$\left({ }^{\star}\right)$ Year end 1998, $\left({ }^{*}\right)$ Pro-forma statements after merger, $\left({ }^{* \star *}\right)$ Year-end 2/99. Grey shadow indicates public bank. Source: FitchIBCA and Capital Data BondWare 
Figure 1

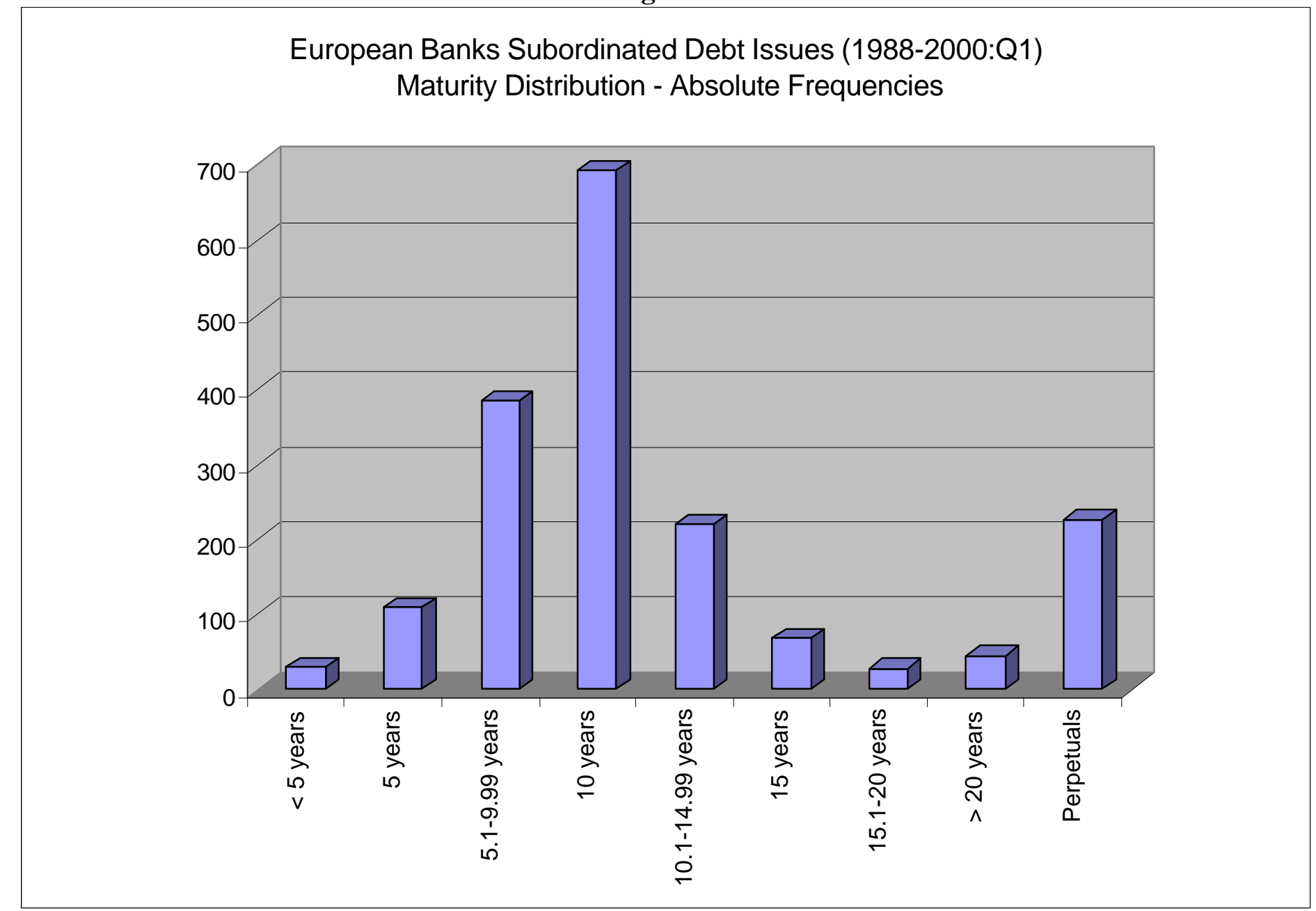


Figure 2

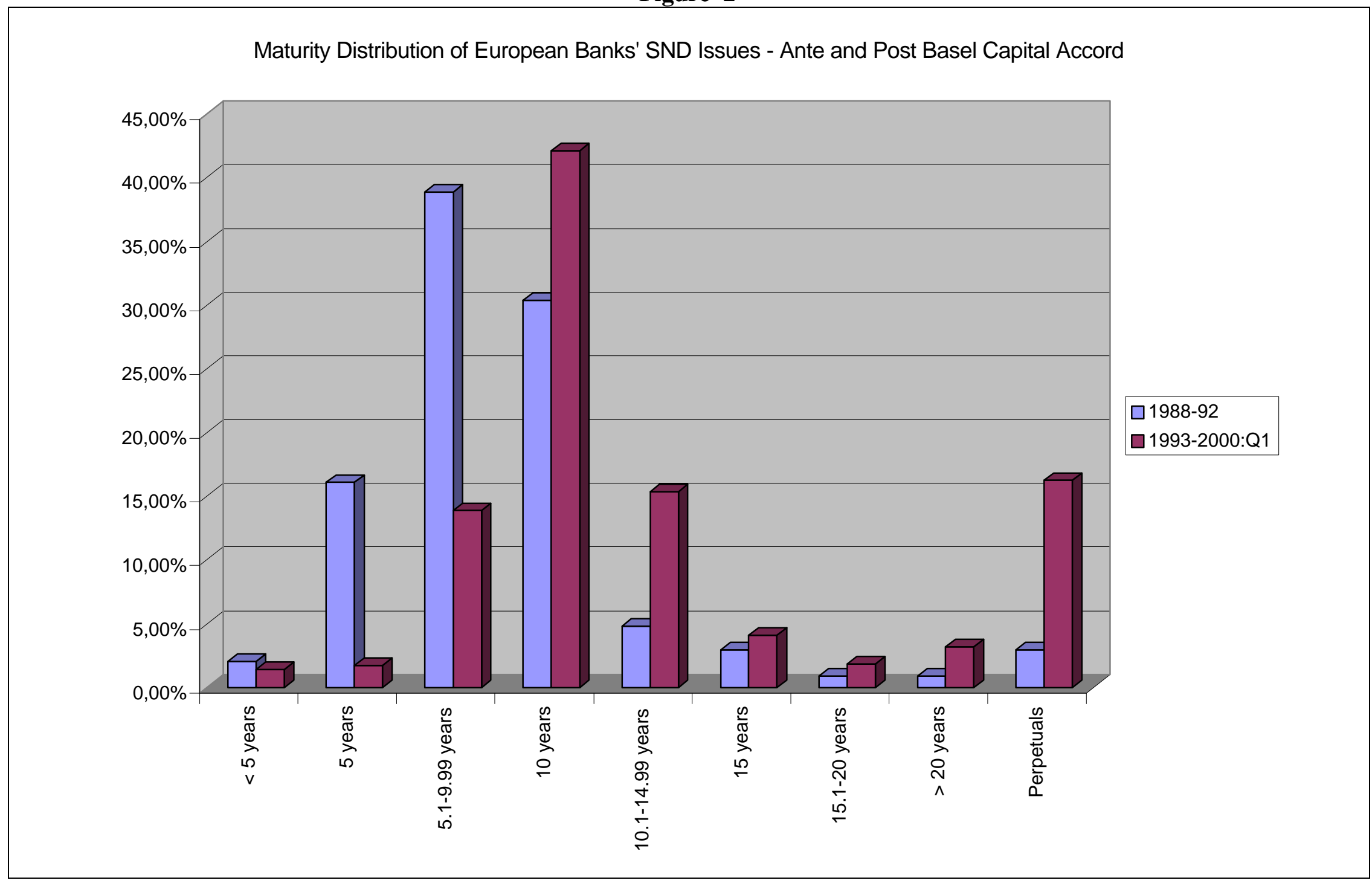


Figure 3

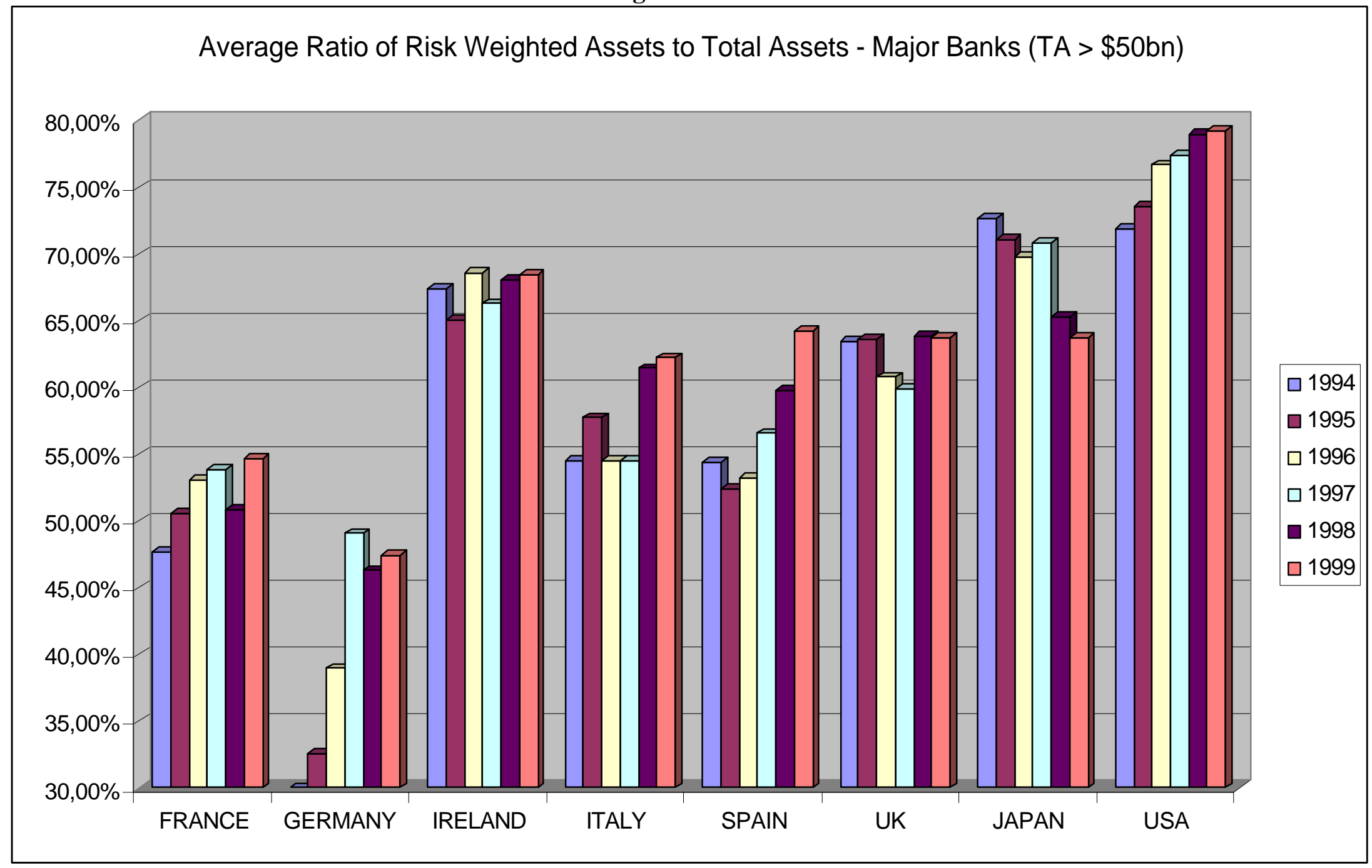

Year end March 1999 for Japanese banks. Source: FitchIBCA. 
Table 5 - European banks SND issues by country (1988-1Q:2000)

\begin{tabular}{|c|c|c|c|c|c|c|c|c|c|c|c|c|c|c|c|c|c|c|c|}
\hline & & & & \multicolumn{5}{|c|}{ Maturity $\left({ }^{*}\right)$} & \multicolumn{5}{|c|}{ Amount (USD mln) } & \multicolumn{2}{|c|}{$\begin{array}{l}\text { Fixed Rate } \\
\text { Issues }\end{array}$} & \multicolumn{2}{|c|}{$\begin{array}{l}\text { Perpetual } \\
\text { Issues }\end{array}$} & \multicolumn{2}{|c|}{$\begin{array}{l}\text { Callable } \\
\text { Issues }\end{array}$} \\
\hline Country & $\begin{array}{l}\text { N. of } \\
\text { Issues }\end{array}$ & $\begin{array}{c}\text { N. of } \\
\text { Issuers }\end{array}$ & $\begin{array}{l}\text { N. of } \\
\text { Issues } \\
\text { per } \\
\text { Issuer }\end{array}$ & Mean & Mode & Min & Max & $\begin{array}{l}\text { St. } \\
\text { Dev. }\end{array}$ & Total & Mean & Min & Max & $\begin{array}{c}\text { St. } \\
\text { Dev. }\end{array}$ & N. & $\begin{array}{l}\text { \% of } \\
\text { Total }\end{array}$ & N. & $\begin{array}{l}\% \text { of } \\
\text { Total }\end{array}$ & N. & $\begin{array}{l}\text { \% of } \\
\text { Total }\end{array}$ \\
\hline AUS & 68 & 13 & 5.2 & 12.74 & 10 & 4 & 30 & 5.4 & 3,892 & 57.2 & 3.02 & 700 & 92.6 & 44 & 64.7 & 4 & 5.88 & 15 & 22.1 \\
\hline BEL & 136 & 8 & 17.0 & 7.76 & 10 & 3 & 29.5 & 3.7 & 8,619 & 63.4 & 1.84 & 600 & 92.9 & 127 & 93.4 & 21 & 15.44 & 19 & 13.9 \\
\hline DEN & 40 & 11 & 3.6 & 8.02 & 10 & 5 & 12 & 2.1 & 4,205 & 105.1 & 3.78 & 300 & 89.2 & 19 & 47.5 & 0 & 0.00 & 14 & 35.0 \\
\hline FIN & 50 & 5 & 10.0 & 7.13 & 10 & 5 & 10 & 1.9 & 5,312 & 106.2 & 7.87 & 300 & 84.8 & 36 & 72.0 & 9 & 18.00 & 15 & 30.0 \\
\hline FRA & 338 & 34 & 9.9 & 9.60 & 10 & 2.8 & 15 & 2.2 & 27,931 & 82.6 & 1.30 & 800 & 98.3 & 274 & 81.1 & 24 & 7.10 & 34 & 10.1 \\
\hline GER & 331 & 31 & 10.7 & 11.00 & 10 & 2 & 40.5 & 5.5 & 39,842 & 120.4 & 5.26 & 1255 & 141.4 & 253 & 76.4 & 5 & 1.51 & 11 & 3.3 \\
\hline UK & 209 & 21 & 10.0 & 13.35 & 10 & 2.1 & 31 & 6.2 & 65,801 & 315.1 & 17.60 & 1308 & 215.1 & 151 & 72.2 & 71 & 33.97 & 83 & 39.7 \\
\hline GRE & 2 & 1 & 2.0 & 10.00 & 10 & 10 & 10 & 0.0 & 181 & 90.4 & 98.54 & 182 & 59.1 & 0 & 0.0 & 0 & 0.00 & 2 & 100.0 \\
\hline IRE & 22 & 6 & 3.7 & 11.01 & 10 & 10 & 15 & 1.6 & 4,404 & 200.2 & 22.47 & 588 & 139.6 & 9 & 40.9 & 12 & 54.55 & 11 & 50.0 \\
\hline ITA & 122 & 19 & 6.4 & 8.34 & 10 & 2 & 15 & 2.7 & 18,639 & 152.8 & 8.51 & 630 & 121.1 & 51 & 41.8 & 5 & 4.10 & 18 & 14.7 \\
\hline LUX & 72 & 12 & 6.0 & 8.37 & 10 & 5 & 15 & 2.0 & 4,183 & 58.1 & 7.05 & 300 & 42.9 & 65 & 90.3 & 2 & 2.78 & 2 & 2.8 \\
\hline $\mathrm{NL}$ & 78 & 12 & 6.5 & 11.46 & 10 & 2 & 100 & 11.0 & 18,295 & 234.6 & 5.55 & 1250 & 242.3 & 65 & 83.3 & 4 & 5.13 & 5 & 6.4 \\
\hline NOR & 36 & 9 & 4.0 & 7.39 & 5 & 5 & 12 & 2.5 & 1,975 & 54.9 & 7.69 & 150 & 45.8 & 20 & 55.5 & 4 & 11.11 & 16 & 44.4 \\
\hline POR & 20 & 10 & 2.0 & 10.00 & 10 & 10 & 10 & 0.0 & 2,134 & 106.7 & 11.05 & 295 & 76.0 & 2 & 10.0 & 7 & 35.00 & 11 & 55.0 \\
\hline SPA & 80 & 10 & 8.0 & 10.54 & 10 & 5 & 30 & 3.5 & 19,772 & 247.2 & 16.52 & 1135 & 216.2 & 55 & 68.7 & 28 & 35.00 & 29 & 36.25 \\
\hline SWE & 64 & 9 & 7.1 & 8.25 & 10 & 4.2 & 15 & 2.9 & 6,502 & 101.6 & 8.34 & 500 & 108.4 & 39 & 60.9 & 17 & 26.56 & 17 & 26.6 \\
\hline SWI & 135 & 14 & 9.6 & 10.63 & 10 & 3 & 30 & 3.7 & 20,833 & 154.3 & 1.11 & 500 & 99.9 & 122 & 90.4 & 11 & 8.15 & 12 & 8.9 \\
\hline Total & 1803 & 225 & 8.0 & 10.10 & 10 & 2 & 100 & 4.9 & 252,520 & 140.1 & 1.11 & 1308 & 160.1 & 1,332 & 73.9 & 224 & 12.42 & 314 & 17.4 \\
\hline
\end{tabular}

(*) Excluding perpetual issues. Source: Capital Data BondWare. 
Table 6 - European banks SND issues by year (1988-1Q:2000)

\begin{tabular}{|c|c|c|c|c|c|c|c|c|c|c|c|c|c|c|c|c|c|}
\hline & & \multicolumn{5}{|c|}{ Maturity $\left(^{*}\right)$} & \multicolumn{5}{|c|}{ Amount (USD mln) } & \multicolumn{2}{|c|}{ Fixed Rate Issues } & \multicolumn{2}{|c|}{ Perpetual Issues } & \multicolumn{2}{|c|}{ Callable Issues } \\
\hline Year & $\begin{array}{l}\text { N. of } \\
\text { Issues }\end{array}$ & Mean & Mode & Min & Max & $\begin{array}{l}\text { Std. } \\
\text { Dev. }\end{array}$ & Total & Mean & Min & Max & St. Dev. & N. & $\%$ of Total & $\mathrm{N}$. & $\%$ of Total & $\mathrm{N}$. & $\begin{array}{l}\text { \% of } \\
\text { Total }\end{array}$ \\
\hline 1988 & 107 & 8.0 & 5.0 & 4.0 & 25.3 & 4.0 & 8,897 & 83.1 & 7.5 & 500.0 & 100.6 & 93 & $86.92 \%$ & 1 & $0.93 \%$ & 0 & $0.00 \%$ \\
\hline 1989 & 52 & 8.1 & 6.0 & 5.0 & 20.0 & 3.7 & 4,838 & 93.0 & 7.1 & 551.3 & 140.0 & 39 & $75.00 \%$ & 6 & $11.54 \%$ & 0 & $0.00 \%$ \\
\hline 1990 & 112 & 7.3 & 7.0 & 3.0 & 15.0 & 2.5 & 6,296 & 56.2 & 5.8 & 487.3 & 87.0 & 91 & $81.25 \%$ & 3 & $2.68 \%$ & 0 & $0.00 \%$ \\
\hline 1991 & 128 & 7.7 & 7.0 & 5.0 & 30.0 & 3.4 & 8,162 & 63.8 & 7.1 & 750.0 & 102.9 & 120 & $93.75 \%$ & 3 & $2.34 \%$ & 0 & $0.00 \%$ \\
\hline 1992 & 141 & 9.8 & 10.0 & 2.8 & 21.8 & 2.2 & 15,260 & 108.2 & 8.9 & 809.0 & 109.5 & 104 & $73.76 \%$ & 3 & $2.13 \%$ & 0 & $0.00 \%$ \\
\hline 1993 & 190 & 11.4 & 10.0 & 5.0 & 100.0 & 7.9 & 22,649 & 119.2 & 8.9 & 1255.8 & 123.1 & 117 & $61.58 \%$ & 18 & $9.47 \%$ & 24 & $12.63 \%$ \\
\hline 1994 & 160 & 10.1 & 10.0 & 4.0 & 30.0 & 3.3 & 13,454 & 84.1 & 1.3 & 596.7 & 92.4 & 115 & $71.88 \%$ & 13 & $8.13 \%$ & 26 & $16.25 \%$ \\
\hline 1995 & 158 & 10.8 & 10.0 & 3.0 & 30.0 & 4.4 & 22,978 & 145.4 & 10.1 & 1000.0 & 127.8 & 112 & $70.89 \%$ & 14 & $8.86 \%$ & 27 & $17.09 \%$ \\
\hline 1996 & 151 & 11.1 & 10.0 & 2.0 & 30.0 & 4.5 & 25,685 & 170.1 & 18.6 & 800.0 & 134.1 & 100 & $66.23 \%$ & 32 & $21.19 \%$ & 57 & $37.75 \%$ \\
\hline 1997 & 157 & 10.6 & 10.0 & 5.0 & 24.3 & 2.5 & 27,638 & 176.0 & 1.1 & 750.0 & 136.7 & 107 & $68.15 \%$ & 34 & $21.66 \%$ & 51 & $32.48 \%$ \\
\hline 1998 & 142 & 10.6 & 10.0 & 2.0 & 30.0 & 3.5 & 24,238 & 170.7 & 3.3 & 831.7 & 153.3 & 110 & $77.46 \%$ & 28 & $19.72 \%$ & 38 & $26.76 \%$ \\
\hline 1999 & 236 & 12.1 & 10.0 & 2.0 & 40.5 & 7.2 & 55,713 & 236.1 & 1.8 & 1308.2 & 249.9 & 170 & $72.03 \%$ & 53 & $22.46 \%$ & 76 & $32.20 \%$ \\
\hline 2000 Q1 & 64 & 10.3 & 10.0 & 2.0 & 20.0 & 3.1 & 15,296 & 239.0 & 3.0 & 1000.0 & 237.3 & 53 & $82.81 \%$ & 12 & $18.75 \%$ & 11 & $17.19 \%$ \\
\hline N.A. & 5 & na & na & na & na & na & 1,418 & 283.6 & 174.3 & 433.0 & 127.8 & 1 & $20.00 \%$ & 4 & $80.00 \%$ & 4 & $80.00 \%$ \\
\hline TOTAL & 1803 & 10.10 & 10.0 & 2.0 & 100.0 & 4.9 & 252,520 & 140.1 & 1.1 & 1308.2 & 160.3 & 1,332 & $73.88 \%$ & 224 & $12.42 \%$ & 314 & $17.42 \%$ \\
\hline
\end{tabular}

(*) Excluding perpetual issues. Source: Capital Data BondWare. 
Table 7 - European banks SND issues by currency (1988-1Q:2000)

\begin{tabular}{|c|c|c|c|c|c|c|c|c|c|c|}
\hline & & & \multicolumn{2}{|c|}{ Amount (USD mln) } & \multicolumn{2}{|c|}{ Fixed Rate Issues } & \multicolumn{2}{|c|}{ Perpetual Issues } & \multicolumn{2}{|c|}{ Callable Issues } \\
\hline & N. of Issues & Avg. Maturity $\left(^{*}\right)$ & Total & Avg. per Issue & Number & $\%$ of Total & Number & $\%$ of Total & Number & $\%$ of Total \\
\hline $\mathrm{DFL}$ & 48 & 10.1 & 8,815 & 183.6 & 48 & $100.0 \%$ & 5 & $10.4 \%$ & 5 & $10.4 \%$ \\
\hline$\overline{\mathrm{DKR}}$ & 14 & 9.1 & 822 & 58.7 & 13 & $92.9 \%$ & 1 & $7.1 \%$ & 1 & $7.1 \%$ \\
\hline $\mathrm{DM}$ & 70 & 9.5 & 12,553 & 179.3 & 50 & $71.4 \%$ & 8 & $11.4 \%$ & 12 & $17.1 \%$ \\
\hline ESC & 17 & 9.8 & 1,088 & 64.0 & 1 & $5.9 \%$ & 0 & $0.0 \%$ & 8 & $47.1 \%$ \\
\hline FFR & 109 & 10.6 & 10,745 & 98.6 & 95 & $87.2 \%$ & 8 & $7.3 \%$ & 14 & $12.8 \%$ \\
\hline LFR & 459 & 7.5 & 12,745 & 27.8 & 458 & $99.8 \%$ & 0 & $0.0 \%$ & 0 & $0.0 \%$ \\
\hline LIT & 38 & 8.4 & 6,972 & 183.5 & 12 & $31.6 \%$ & 1 & $2.6 \%$ & 11 & $28.9 \%$ \\
\hline PTA & 9 & 11.0 & 867 & 96.3 & 8 & $88.9 \%$ & 0 & $0.0 \%$ & 0 & $0.0 \%$ \\
\hline $\mathrm{SCH}$ & 24 & 15.7 & 430 & 17.9 & 17 & $70.8 \%$ & 1 & $4.2 \%$ & 10 & $41.7 \%$ \\
\hline SFR & 116 & 10.3 & 12,772 & 110.1 & 114 & $98.3 \%$ & 1 & $0.9 \%$ & 2 & $1.7 \%$ \\
\hline STG & 148 & 14.1 & 36,443 & 246.2 & 115 & $77.7 \%$ & 50 & $33.8 \%$ & 47 & $31.8 \%$ \\
\hline USD & 406 & 11.1 & 87,001 & 214.3 & 143 & $35.2 \%$ & 91 & $22.4 \%$ & 136 & $33.5 \%$ \\
\hline Others & 23 & 9.5 & 2,329 & 101.3 & 9 & $39.1 \%$ & 2 & $8.7 \%$ & 2 & $8.7 \%$ \\
\hline TOTAL & 1803 & 10.1 & 252,520 & 140.1 & 1,332 & 0.7 & 224 & $12.4 \%$ & 314 & $17.4 \%$ \\
\hline
\end{tabular}

$\left(^{*}\right)$ Excluding perpetual issues. Source: Capital Data BondWare. 
Table 8 - European banks SND issues by type (1988-1Q:2000)

\begin{tabular}{||l|c|c|l|c|c||}
\hline Interest Rate Type & Number & $\begin{array}{c}\% \text { of } \\
\text { Total }\end{array}$ & Other Features & Number & $\begin{array}{c}\% \text { of } \\
\text { Total }\end{array}$ \\
\hline Fixed Rate & 1289 & 71.5 & Irregular & 277 & 15.36 \\
\hline Floating Rate Notes & 448 & 24.8 & Collared & 96 & 5.32 \\
\hline Fixed Rate Zero Coupon & 29 & 1.6 & Hybrid & 82 & 4.55 \\
\hline Convertible & 15 & 0.8 & Preference Shares & 75 & 4.16 \\
\hline Fixed Rate + Warrant for Equity & 8 & 0.4 & Euro-Fungible & 30 & 1.66 \\
\hline Fixed Rate Convertible Into Floating & 6 & 0.3 & Variable/Auction Rate & 25 & 1.39 \\
\hline Floating Rate Note Extendible & 3 & 0.2 & Dual Currency & 24 & 1.33 \\
\hline Floating Rate Convertible Into Fixed & 2 & 0.1 & Repackaging & 14 & 0.78 \\
\hline Fixed Rate + Warrant for Debt & 2 & 0.1 & Tap & 15 & 0.83 \\
\hline Convertible Preference Shares & 1 & 0.1 & Reverse Floating Rate Notes & 9 & 0.50 \\
\hline \multicolumn{7}{|l|}{} & & Index Linked & 5 & 0.28 \\
\cline { 2 - 6 } & & Asset Back & 4 & 0.22 \\
\cline { 2 - 6 } & & Currency Linked & 3 & 0.17 \\
\hline Total & 1803 & 100.0 & Plain Vanilla & 1526 & 84.63 \\
\hline
\end{tabular}

Source: Capital Data BondWare.

Table 9 - European Banks Subordinated Debt Issues by Market Type

\begin{tabular}{|l|c|c|c|c|c||}
\hline Market Type & $\begin{array}{c}\text { Number of } \\
\text { Issues }\end{array}$ & \% of Total & Total Amount & $\%$ of Total & $\begin{array}{c}\text { Average } \\
\text { Amount }\end{array}$ \\
\hline Domestic - Private Placement & 98 & 5.44 & 7,542 & 2.99 & 77.0 \\
\hline Domestic - Public Issue & 288 & 15.97 & 28,946 & 11.46 & 100.5 \\
\hline Euro - Private Placement & 291 & 16.14 & 13,161 & 5.21 & 45.2 \\
\hline Euro - Public Issue & 800 & 44.37 & 158,029 & 62.58 & 197.5 \\
\hline Foreign - Private Placement & 193 & 10.70 & 6,054 & 2.40 & 31.4 \\
\hline Foreign - Public Issue & 120 & 6.66 & 30,745 & 12.18 & 256.2 \\
\hline Global - Public Issue & 13 & 0.72 & 8,044 & 3.19 & 618.8 \\
\hline Total & 1803 & 100 & 252,520 & 100 & 140.1 \\
\hline
\end{tabular}

Source: Capital Data BondWare.

Table 10 - European Banks Issues of SNDs in Fiscal Havens

\begin{tabular}{|l|c|c|}
\hline & Number of Issues & $\begin{array}{c}\text { \% of Total 1988-2000:Q1 } \\
\text { issues }\end{array}$ \\
\hline Luxembourg & 237 & 13.14 \\
\hline Cayman Islands & 80 & 4.44 \\
\hline Netherland Antilles & 49 & 2.72 \\
\hline Channel Islands & 23 & 1.28 \\
\hline Bahamas & 13 & 0.72 \\
\hline Hong Kong & 12 & 0.67 \\
\hline Total & 414 & 22.96 \\
\hline
\end{tabular}

Source: Capital Data BondWare. 
Table 11 - European Banks SD Issues by Market Listings

\begin{tabular}{|l|c|c|}
\hline Market & Number of issues & $\%$ of Total \\
\hline Luxembourg & 702 & $38.94 \%$ \\
\hline London & 265 & $14.70 \%$ \\
\hline Paris & 148 & $8.21 \%$ \\
\hline Zurich & 88 & $4.88 \%$ \\
\hline Geneva & 74 & $4.10 \%$ \\
\hline Basle & 72 & $3.99 \%$ \\
\hline Frankfurt & 68 & $3.77 \%$ \\
\hline Amsterdam & 67 & $3.72 \%$ \\
\hline Berne & 25 & $1.39 \%$ \\
\hline Lausanne & 24 & $1.33 \%$ \\
\hline Vienna & 24 & $1.33 \%$ \\
\hline AlAF & 20 & $1.11 \%$ \\
\hline Schweizer Borse & 15 & $0.83 \%$ \\
\hline Lisbon & 14 & $0.78 \%$ \\
\hline New York & 12 & $0.67 \%$ \\
\hline Dusseldorf & 11 & $0.61 \%$ \\
\hline Milan & 11 & $0.61 \%$ \\
\hline Dublin & 4 & $0.22 \%$ \\
\hline Munich & 3 & $0.17 \%$ \\
\hline Singapore & 3 & $0.17 \%$ \\
\hline Copenhagen & 2 & $0.11 \%$ \\
\hline Hong Kong & 2 & $0.11 \%$ \\
\hline Madrid & 2 & $0.11 \%$ \\
\hline Brussels & 1 & $0.06 \%$ \\
\hline Total Number of Listed Issues & 1416 & $78.54 \%$ \\
\hline of which listed in more markets & 137 & $21.46 \%$ \\
\hline Unquoted & 387 & $100.00 \%$ \\
\hline Total & 1803 & \\
\hline SOurce Capta Da BonWar & & \\
\hline
\end{tabular}

Source: Capital Data BondWare.

Table 12 - European Banks SND Issues by Market Type (1988-1Q:2000)

\begin{tabular}{|c|c|c|c|c|c|c|c|c|c|c|c|}
\hline & \multicolumn{10}{|c|}{ Listings } \\
\hline & & London & $\begin{array}{l}\% \text { of } \\
\text { Total }\end{array}$ & Lux. & $\begin{array}{l}\text { \% of } \\
\text { Total }\end{array}$ & \begin{tabular}{|c|} 
Other \\
Markets
\end{tabular} & $\begin{array}{l}\text { \% of } \\
\text { Total }\end{array}$ & Unquoted & $\begin{array}{l}\% \text { of } \\
\text { Total }\end{array}$ & \begin{tabular}{|c|} 
Total \\
$\mathrm{N}$. of \\
Issues
\end{tabular} & $\%$ \\
\hline \multirow{2}{*}{ Domestic } & Private Placement & 1 & 1.02 & 7 & 7.1 & 38 & 38.8 & 52 & 53.1 & 98 & 100 \\
\hline & Public Issue & 11 & 3.8 & 22 & 7.6 & 243 & 84.4 & 12 & 4.2 & 288 & 100 \\
\hline \multirow{2}{*}{ Euro } & Private Placement & 12 & 4.1 & 246 & 84.5 & 1 & 0.3 & 32 & 11.0 & 291 & 100 \\
\hline & Public Issue & 229 & 28.6 & 418 & 52.2 & 118 & 14.7 & 35 & 4.4 & 800 & 100 \\
\hline \multirow{2}{*}{ Foreign } & Private Placement & 1 & 0.5 & 1 & 0.5 & 1 & 0.5 & 190 & 98.4 & 193 & 100 \\
\hline & Public Issue & 6 & 5.0 & 2 & 1.7 & 48 & 40.0 & 64 & 53.3 & 120 & 100 \\
\hline \multirow[t]{2}{*}{ Global } & Public Issue & 5 & 38.5 & 6 & 46.1 & 0 & 0.0 & 2 & 15.4 & 13 & 100 \\
\hline & Total & 265 & 14.7 & 702 & 38.9 & 449 & 24.9 & 387 & 21.5 & 1803 & 100 \\
\hline
\end{tabular}

Source: Capital Data BondWare. 
Table 13 - A comparison of European and U.S. Banks SND Issues

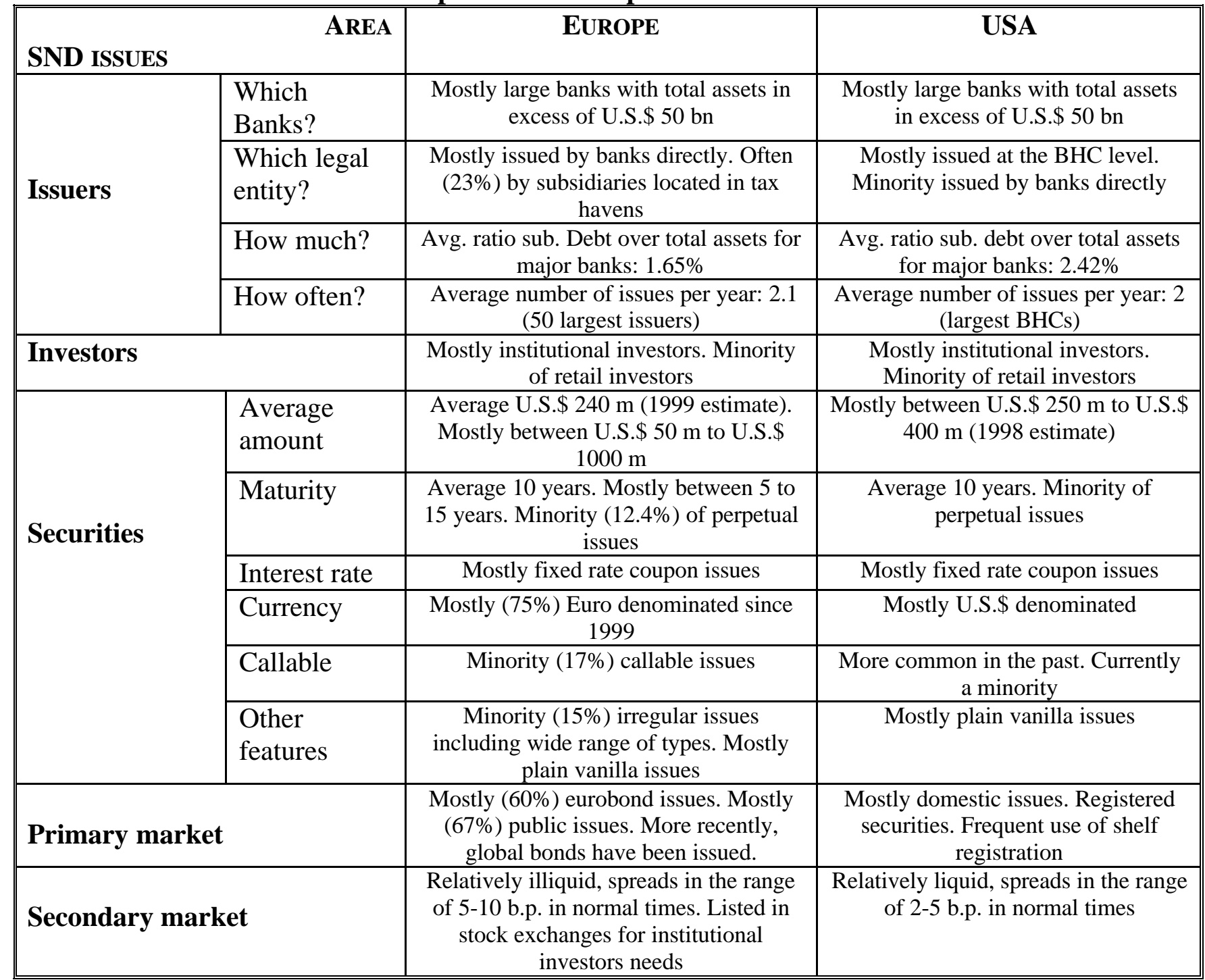

Source: FitchIBCA, Federal Reserve Board (1999), Capital Data BondWare, Interviews to market participants. 


\section{APPENDIX 1 \\ Total Subordinated Debt Outstanding (US\$) - Major International Banks}

(Banks with Total Assets in excess of US\$ 50bn)

\begin{tabular}{|c|c|c|c|c|c|c|c|c|}
\hline Country & Bank & 1999 & 1998 & 1997 & 1996 & 1995 & 1994 & 1993 \\
\hline \multirow{3}{*}{$\mathbf{A T}$} & Bank Austria AG (includes Creditanstalt)(**) & 3.193 & 3.632 & 2.973 & 2.408 & 2.054 & 2.078 & 825 \\
\hline & Erste Bank der Oesterreichischen Sparkassen AG (**) & 1.312 & 1.312 & 986 & 830 & 0 & 0 & 0 \\
\hline & Total & 4.505 & 4.944 & 3.960 & 3.238 & 2.054 & 2.078 & 825 \\
\hline \multirow{7}{*}{ BEL } & Fortis (includes ASLK-CGER and Generale Bank) (**) & 7.142 & 7.142 & 6.065 & 5.239 & 5.674 & 4.188 & 3.183 \\
\hline & Group Dexia (Combined) & 3.121 & 3.116 & 2.937 & 2.629 & 2.623 & NA & $\mathrm{NA}$ \\
\hline & Almanij (includes KBC Bank) & 5.274 & 5.327 & 4.745 & 4.074 & 3.446 & 2.883 & 1.960 \\
\hline & Crédit Communal de Belgique (**) & 2.122 & 2.122 & 1.961 & 1.639 & 1.629 & 1.351 & 1.023 \\
\hline & $\begin{array}{l}\text { Bank Brussel Lambert - BBL-Banque Bruxelles Lambert } \\
\text { s.a./n.v. - BBL }\end{array}$ & 2.450 & 2.570 & 2.118 & 1.960 & 1.766 & 1.360 & 1.103 \\
\hline & Groupe Arcofin (includes Artesia Banking Corporation)(**) & 1.721 & 1.721 & 1.485 & 542 & 526 & 430 & 231 \\
\hline & Total & 21.830 & 21.999 & $\mathbf{1 9 . 3 1 0}$ & $\mathbf{1 6 . 0 8 2}$ & 15.664 & $\mathbf{1 0 . 2 1 2}$ & $\mathbf{7 . 5 0 0}$ \\
\hline \multirow{4}{*}{ DEN } & Den Danske Bank & 3.021 & 2.608 & 2.694 & 304 & 315 & 303 & 370 \\
\hline & Unidanmark Group (The) & 1.111 & 833 & 0 & 100 & 100 & 92 & 251 \\
\hline & Kapital Holding (includes Realkredit Danmark) & 957 & 858 & 439 & 505 & 541 & 493 & 443 \\
\hline & Total & 5.089 & 4.299 & 3.134 & 909 & 956 & 889 & 1.064 \\
\hline FIN & Merita NordBanken Group & 3.064 & 1.307 & 1.330 & 1.697 & 1.809 & 1.244 & 1.164 \\
\hline \multirow{12}{*}{ FRA } & BNP+Paribas & 9.736 & 11.141 & 9.445 & 10.280 & 10.183 & 9.939 & 9.630 \\
\hline & Crédit Agricole CA & 4.626 & 4.707 & 4.161 & 4.259 & 3.429 & 3.155 & 2.610 \\
\hline & Société Générale & 6.479 & 7.184 & 6.808 & 6.129 & 5.574 & 4.355 & 4.166 \\
\hline & Groupe Caisse d'Epargne $(* *)$ & 142 & 142 & 35 & 40 & 42 & 39 & $\mathrm{NA}$ \\
\hline & Groupe Banques Populaires (includes Natexis) (**) & 3.084 & 3.084 & 1.554 & 1.707 & 1.733 & NA & NA \\
\hline & Crédit Lyonnais & 4.005 & 5.695 & 5.589 & 6.517 & 7.451 & 7.342 & 5.962 \\
\hline & Groupe Caisse des Dépôts $(* *)$ & 5 & 5 & 4 & 0 & 2 & 18 & 5 \\
\hline & Credit Mutuel Centre Est Europe (**) & 2.636 & 2.636 & 34 & 39 & $\mathrm{NA}$ & NA & $\mathrm{NA}$ \\
\hline & Dexia Crédit Local de France $(* *)$ & 994 & 994 & 977 & 990 & 992 & 877 & 702 \\
\hline & Crédit Industriel et Commercial - CIC & 1.466 & 1.614 & 1.428 & 1.675 & 1.642 & 1.330 & 1.019 \\
\hline & Crédit Commercial de France & 697 & 1.024 & 802 & 1.018 & 1.181 & 1.104 & 1.259 \\
\hline & Total & 33.871 & 38.227 & $\mathbf{3 0 . 8 3 7}$ & 32.654 & 32.229 & 28.159 & 25.354 \\
\hline \multirow{14}{*}{ GER } & Deutsche Bank AG (IAS) & 11.053 & 6.072 & 5.712 & 4.969 & 3.906 & 3.561 & NA \\
\hline & Bayerische Hypo-und Vereinsbank (IAS) & 9.401 & 7.430 & 5.610 & 6.081 & 6.068 & 4.475 & 3.938 \\
\hline & Westdeutsche Landesbank Girozentrale WestLB (**) & 4.371 & 4.371 & 3.257 & 2.754 & 2.653 & 2.614 & 2.067 \\
\hline & Dresdner Bank AG (IAS) & 8.049 & 5.956 & 5.498 & NA & NA & $\mathrm{NA}$ & $\mathrm{NA}$ \\
\hline & Commerzbank AG (IAS) & 5.871 & 4.198 & 4.062 & NA & NA & NA & NA \\
\hline & Bayerische Landesbank Girozentrale (**) & 3.965 & 3.965 & 3.131 & 3.203 & 2.779 & 1.786 & 1.426 \\
\hline & Deutsche Genossenschaftsbank DG BANK (IAS) (**) & 2.531 & 2.531 & 2.965 & 327 & 290 & NA & NA \\
\hline & $\begin{array}{l}\text { Landesbank Baden-Wuerttemberg (includes SudWestdeutsche } \\
\text { Landesbank) }(* *)\end{array}$ & 3.794 & 3.794 & 3.571 & 1.908 & 854 & 845 & 552 \\
\hline & Bankgesellschaft Berlin AG $(* *)$ & 2.477 & 2.477 & 1.414 & 227 & 199 & 167 & NA \\
\hline & Norddeutsche Landesbank Girozentrale NORD/LB (**) & 1.829 & 1.829 & 1.517 & 1.374 & 1.177 & 816 & 534 \\
\hline & DePfa Deutsche Pfandbrief Bank AG (**) & 542 & 542 & 487 & 496 & 488 & 452 & 398 \\
\hline & Landesbank Schleswig-Holstein Girozentrale - LB Kiel (**) & 1.317 & 1.317 & 1.214 & 819 & 621 & 610 & 59 \\
\hline & Landesbank Hessen-Thueringen Girozentrale - HELABA $(* *)$ & 897 & 897 & 711 & 714 & 627 & 604 & 423 \\
\hline & Deutsche Siedlungs- und Landesrentenbank - DSL Bank (**) & 315 & 315 & 305 & 315 & 312 & 297 & 208 \\
\hline
\end{tabular}




\begin{tabular}{|c|c|c|c|c|c|c|c|c|}
\hline & Landesbank Rheinland-Pfalz Girozentrale (**) & 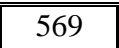 & 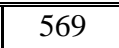 & 467 & 424 & 4990 & 282 & 240 \\
\hline & Hamburgische Landesbank - Girozentrale & 988 & 898 & 696 & 641 & NA & NA & NA \\
\hline & BHW Holdings AG $(* *)$ & 257 & 257 & 238 & 246 & 7 & NA & NA \\
\hline & DGZ - DekaBank Deutsche Kommunalbank (**) & 190 & 190 & 177 & 203 & 55 & 51 & 46 \\
\hline & BHF-BANK AG (IAS) $(* *)$ & 261 & 261 & 244 & NA & NA & NA & NA \\
\hline & Total & $\mathbf{5 8 . 6 7 7}$ & 47.871 & 41.278 & 24.702 & 20.527 & 16.559 & 9.890 \\
\hline \multirow{3}{*}{ IRE } & Allied Irish Banks plc & 1.989 & 1.136 & 1.129 & 794 & 650 & 664 & 756 \\
\hline & Bank of Ireland (3/2000) & 1.922 & 874 & 904 & 581 & 269 & 428 & 267 \\
\hline & Total & 3.911 & 2.010 & 2.033 & 1.375 & 920 & 1.092 & 1.023 \\
\hline \multirow{7}{*}{ ITA } & Banca Intesa (includes BCI) & 8.832 & 6.215 & 3.858 & 4.207 & 1.676 & 1.632 & 1.422 \\
\hline & UniCredito Italiano SpA & 1.412 & 1.490 & 1.683 & NA & NA & NA & NA \\
\hline & San Paolo IMI & 1.512 & 1.774 & 2.021 & 2.357 & 2.137 & 1.450 & 1.010 \\
\hline & Banca di Roma & 2.506 & 1.538 & 1.429 & 1.588 & 1.442 & 501 & 200 \\
\hline & Banca Monte dei Paschi di Siena SpA (Gruppo) & 1.146 & 564 & 318 & 423 & 300 & 56 & 45 \\
\hline & Banca Nazionale del Lavoro SpA - BNL & 1.970 & 1.900 & 933 & 1.047 & 1.248 & 926 & 839 \\
\hline & Total & $\mathbf{1 7 . 3 7 9}$ & 13.481 & 10.243 & 9.621 & 6.803 & 4.566 & 3.515 \\
\hline \multirow{24}{*}{$\mathbf{J N P}(*)$} & Bank of Tokyo - Mitsubishi & 18.291 & 15.874 & 14.545 & 15.577 & 18.022 & 13.582 & 12.477 \\
\hline & Fuji Bank Ltd. & 20.704 & 12.940 & 13.952 & 12.206 & 12.794 & 10.395 & 9.564 \\
\hline & Sumitomo Bank Ltd & 14.079 & 13.220 & 12.874 & 13.074 & 14.051 & 10.198 & 9.276 \\
\hline & Dai-Ichi Kangyo Bank Ltd DKB & 13.946 & 11.549 & 12.500 & 11.694 & 12.001 & 9.691 & 8.839 \\
\hline & Sanwa Bank Ltd & 13.865 & 13.341 & 12.558 & 12.517 & 11.841 & 9.959 & 9.150 \\
\hline & Sakura Bank Limited (The) & 13.432 & 13.115 & 12.602 & 11.953 & 12.253 & 9.899 & 9.241 \\
\hline & Industrial Bank of Japan Ltd & 11.987 & 10.786 & 7.774 & 8.609 & 7.577 & 6.581 & 5.690 \\
\hline & Tokai Bank Ltd. & 8.304 & 7.702 & 6.937 & 6.759 & 7.838 & 6.676 & 5.605 \\
\hline & Asahi Bank Ltd & 8.620 & 7.284 & 6.210 & 6.291 & 5.572 & 4.356 & 3.873 \\
\hline & Long Term Credit Bank of Japan Ltd. LTCB & 8.890 & 8.273 & 8.534 & 8.417 & 7.612 & 5.202 & 4.670 \\
\hline & Mitsubishi Trust and Banking Corporation (The) & 3.940 & 2.835 & 2.534 & 2.250 & 1.362 & 871 & 798 \\
\hline & Sumitomo Trust \& Banking Company Ltd & 4.110 & 3.870 & 2.003 & 1.587 & 1.552 & 1.081 & 1.016 \\
\hline & Daiwa Bank Ltd & 4.322 & 4.185 & 3.491 & 4.291 & 4.777 & 3.124 & 2.664 \\
\hline & Nippon Credit Bank Ltd (The) & 2.308 & 2.391 & 3.782 & 4.584 & 5.549 & 3.603 & 3.251 \\
\hline & Mitsui Trust \& Banking Company Limited (The) & 3.449 & 1.908 & 1.193 & 1.223 & 1.231 & 485 & 430 \\
\hline & Toyo Trust and Banking Co., Ltd & 2.561 & 2.388 & 1.674 & 1.398 & 971 & 881 & 816 \\
\hline & Bank of Yokohama, Ltd (The) & 4.528 & 2.472 & 2.401 & 2.699 & 2.321 & 1.806 & 1.648 \\
\hline & Yasuda Trust \& Banking Co. (The) & 3.303 & 3.045 & 2.270 & 2.529 & 1.680 & 1.276 & 1.226 \\
\hline & Chiba Bank Ltd. & 987 & NA & NA & NA & NA & NA & NA \\
\hline & Chuo Trust \& Banking Co., Ltd (The) & 1.214 & NA & NA & 1.110 & 1.119 & 969 & 859 \\
\hline & Joyo Bank Ltd. & 456 & NA & NA & NA & NA & NA & NA \\
\hline & Hokuriku Bank Ltd. & 1.571 & NA & 1.407 & 1.355 & 1.447 & 1.300 & 1.043 \\
\hline & Hokkaido Takushoku Bank Ltd (**) & 1.874 & 1.874 & 2.464 & 2.729 & 2.825 & 2.474 & 2.316 \\
\hline & Total & 166.742 & 139.054 & 131.704 & 132.853 & 134.396 & 104.407 & 94.453 \\
\hline \multirow{4}{*}{ NET } & ABN Amro Holding NV & 11.039 & 10.477 & 9.965 & 8.780 & 7.293 & 6.098 & 5.318 \\
\hline & ING Group & 7.974 & 8.233 & 5.132 & 4.782 & 3.825 & 3.216 & 2.664 \\
\hline & Rabobank Group & 60 & 81 & 60 & 22 & 17 & 16 & 0 \\
\hline & Total & $\mathbf{1 9 . 0 7 3}$ & 18.791 & $\mathbf{1 5 . 1 5 7}$ & $\mathbf{1 3 . 5 8 3}$ & $\mathbf{1 1 . 1 3 5}$ & 9.330 & 7.982 \\
\hline \multirow[b]{3}{*}{ SPA } & Banco Santander Central Hispano (Proforma) & 8.117 & 7.241 & 6.642 & 6.449 & 5.470 & 3.807 & 2.281 \\
\hline & Banco Bilbao Vizcaya Argentaria SA (Proforma) & 3.312 & 3.474 & 3.468 & 3.389 & 2.477 & 1.009 & 666 \\
\hline & Caja de Ahorros y Pensiones de Barcelona, LA CAIXA & 1.541 & 617 & 590 & 682 & 737 & 679 & 629 \\
\hline
\end{tabular}




\begin{tabular}{|c|c|c|c|c|c|c|c|c|}
\hline & Caja Madrid & 4770 & 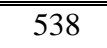 & 40 & 46 & 49 & 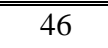 & 42 \\
\hline & Total & $\mathbf{1 3 . 4 4 2}$ & $\mathbf{1 1 . 8 7 1}$ & $\mathbf{1 0 . 7 3 9}$ & 10.566 & 8.733 & 5.541 & 3.619 \\
\hline \multirow{5}{*}{ SWE } & Svenska Handelsbanken & 2.412 & 2.870 & 2.949 & 1.790 & 1.926 & 1.625 & 1.344 \\
\hline & Foereningssparbanken - Swedbank & 3.080 & 1.075 & 980 & 1.158 & 1.444 & 1.509 & 1.356 \\
\hline & Skandinaviska Enskilda Banken & 914 & 1.023 & 1.288 & 1.483 & 1.688 & 1.986 & 2.279 \\
\hline & Nordbanken AB (1999 included in Merita) & 0 & 1.056 & 855 & 990 & 1.125 & 1.299 & 1.454 \\
\hline & Total & 6.406 & 6.023 & 6.073 & 5.421 & 6.184 & 6.419 & 6.433 \\
\hline \multirow{3}{*}{ SWI } & UBS AG (IAS) & 8.982 & 9.716 & 5.323 & 4.634 & 4.847 & 2.631 & 2.856 \\
\hline & Credit Suisse Group (**) & 12.031 & 12.031 & 11.431 & 9.950 & 8.686 & 7.102 & 5.678 \\
\hline & Total & 21.013 & 21.747 & 16.754 & $\mathbf{1 4 . 5 8 4}$ & $\mathbf{1 3 . 5 3 3}$ & 9.733 & 8.534 \\
\hline \multirow{11}{*}{$\mathbf{U K}$} & HSBC Holdings Plc & 12.188 & 7.597 & 7.281 & 7.144 & 5.836 & 5.388 & 4.931 \\
\hline & Barclays Bank Plc & 4.590 & 3.314 & 2.100 & 2.465 & 2.576 & 2.630 & 3.349 \\
\hline & National Westminster Bank Plc - NatWest & 12.153 & 4.668 & 4.606 & 4.337 & 4.008 & 4.209 & 4.208 \\
\hline & Abbey National Plc & 5.294 & 3.996 & 3.053 & 2.990 & 2.793 & 2.375 & 1.286 \\
\hline & Lloyds TSB Group plc & 5.156 & 4.164 & 4.455 & 4.304 & 3.568 & 3.636 & 1.757 \\
\hline & Halifax PLC & 3.876 & 2.630 & 2.697 & 2.620 & NA & NA & NA \\
\hline & Bank of Scotland & 3.248 & 1.092 & 1.178 & 1.328 & 1.370 & 1.061 & 861 \\
\hline & Royal Bank of Scotland plc (The) & 3.311 & 2.694 & 2.325 & 1.504 & 1.327 & 668 & 414 \\
\hline & Standard Chartered Plc & 1.523 & 363 & 362 & 530 & 609 & 588 & 570 \\
\hline & Woolwich Plc & 1.361 & 1.150 & 1.144 & 1.111 & NA & NA & NA \\
\hline & Total & $\mathbf{5 2 . 7 0 0}$ & 31.668 & 29.200 & 28.334 & 22.088 & 20.554 & $\mathbf{1 7 . 3 7 6}$ \\
\hline \multirow{22}{*}{ USA } & Citigroup & 8.773 & 7.777 & 7.026 & 7.162 & 6.842 & 6.531 & 6.186 \\
\hline & $\begin{array}{l}\text { Bank of America Corporation (for 1993-97 includes data of } \\
\text { Nationsbank Texas) }\end{array}$ & 16.036 & 16.479 & 7.571 & 6.854 & 5.230 & 3.637 & 3.238 \\
\hline & \begin{tabular}{|l|} 
Chase Manhattan Corporation (The) \\
\end{tabular} & 8.689 & 8.484 & 8.197 & 8.498 & 3.260 & 2.989 & 2.520 \\
\hline & Bank One Corporation (includes First Chicago NBD Corp.) & 7.337 & 7.339 & 6.760 & 5.747 & 4.939 & 2.604 & 2.498 \\
\hline & J.P. Morgan \& Co. Incorporated & 6.130 & 5.114 & 5.675 & 4.261 & 4.077 & 3.875 & 3.047 \\
\hline & First Union Corporation & 6.723 & 9.526 & 5.298 & 4.295 & 3.115 & 2.212 & 1.767 \\
\hline & Wells Fargo \& Company & 2.587 & 2.719 & 2.199 & 2.550 & 1.066 & 1.260 & 1.515 \\
\hline & $\begin{array}{l}\text { Fleet Boston Financial Corporation (for 1993-98 includes data } \\
\text { of BankBoston Corp) }\end{array}$ & 6.681 & 6.080 & 4.069 & 3.479 & 2.929 & 2.574 & 2.080 \\
\hline & Suntrust Banks, Inc. & 1.377 & 1.377 & 950 & 850 & 200 & 200 & 109 \\
\hline & HSBC USAs Inc. & 3.428 & 622 & 622 & 747 & 324 & 324 & 324 \\
\hline & National City Corporation & 3.180 & 1.951 & 1.585 & 1.660 & 1.063 & 591 & 348 \\
\hline & KeyCorp & 2.703 & 2.710 & 2.130 & 2.134 & 1.107 & 890 & 597 \\
\hline & US Bancorp & 2.950 & 3.057 & 2.057 & 1.257 & 1.132 & 732 & 532 \\
\hline & PNC Financial Services Group. & 2.227 & 1.581 & 1.496 & 1.155 & 1.460 & 746 & 547 \\
\hline & Bank of New York Company, Inc. (The) & 2.726 & 1.984 & 1.746 & 1.746 & 1.762 & 1.694 & 1.395 \\
\hline & Bankers Trust Corporation & 3.460 & 3.959 & 3.668 & 2.653 & 2.252 & 1.943 & 2.089 \\
\hline & Wachovia Corporation & 2.290 & 2.768 & 1.473 & 1.322 & 1.328 & 831 & 584 \\
\hline & ABN AMRO North America, Inc. & 1.096 & 896 & 741 & 484 & 362 & 361 & 269 \\
\hline & State Street Corporation & 2 & 2 & 3 & 3 & 3 & 3 & 4 \\
\hline & California Federal Bank, a Federal Savings Bank & 99 & 105 & 98 & 54 & 55 & 64 & 64 \\
\hline & Republic New York Corporation (absorbed by HSBC in 12/99) & 0 & 2.646 & 2.650 & 2.400 & 2.406 & 2.406 & 2.272 \\
\hline & Total & 88.493 & 87.178 & 66.013 & $\mathbf{5 9 . 3 1 1}$ & 44.912 & 36.467 & 31.984 \\
\hline
\end{tabular}

(*) Year-end March 31 data for Japanese Banks are reported. (**) 1998 data reported for 1999 when 1999 not available. 